\title{
Tillage, Green Manure And Residue Retention Improve Aggregate-Associated Phosphorus Fractions Under Rice-Wheat Cropping
}

\author{
Sandeep Sharma ( $\nabla$ sandyagro@pau.edu ) \\ Punjab Agricultural University \\ Sukhjinder Kaur \\ Punjab Agricultural University \\ Om Parkash Choudhary \\ Punjab Agricultural University
}

\section{Research Article}

Keywords: Phosphorus fractions, residue retention, green manure, Aggregation, rice-wheat

Posted Date: September 14th, 2021

DOI: https://doi.org/10.21203/rs.3.rs-829292/v1

License: (9) This work is licensed under a Creative Commons Attribution 4.0 International License. Read Full License 


\section{Abstract}

The sustainability of rice-wheat system (RWS) in north-western India is threatened due to the deterioration of soil health and emergence of new challenges of climate change caused by low nutrient use efficiency and large scale burning of crop residues. Phosphorus and phosphatase activities in the soil aggregates affected by different residue management practices remain poorly understood. Thus, soil samples were obtained after a five year field experiment to identify the effect of tillage, green manure and residue management on aggregate-associated phosphorus fractions. In rice, the main plot treatments were combinations of wheat straw and Sesbania green manure (GM) management: (1) puddled transplanted rice (PTR) with no wheat straw (PTRW $)$,

(2) PTR with 25\% wheat stubbles (12-15 cm long) retained $\left(P_{T R W}\right)$, (3) PTR without wheat straw and GM (PTRW + GM), and

(4) PTR with wheat stubbles (25\%) and GM (PTRW $25+G M)$. Three sub-plots treatments in the successive wheat crop were (1) conventional tillage with rice straw removed $\left(C T W_{R 0}\right)$, (2) zero tillage $(\mathrm{ZT})$ with rice straw removed $\left(\mathrm{ZTW}_{\mathrm{RO}}\right)$ and (3) ZT with $100 \%$ rice straw retained as surface mulch $\left(Z T W_{R 100}\right)$. Results of the present study revealed that all phosphorus fractions were significantly higher in PTRW $25+\mathrm{GM}$ followed by $\mathrm{ZTW}_{\mathrm{R} 100}$ compared with $\mathrm{PTRW} / \mathrm{CTW}_{\mathrm{R} 0}$ treatment within both macro- and microaggregates. The total phosphorus $(P)$, available $P$, alkaline phosphatase and phytin- $P$ were significantly higher under $Z T W_{R 100}$ than $\mathrm{CTW}_{\mathrm{RO}}$. Principal component analysis identified $\mathrm{NaOH}-\mathrm{P}_{\mathrm{O}}, \mathrm{NaHCO}_{3}-\mathrm{P}_{\mathrm{i}}$ and $\mathrm{HCl}-\mathrm{P}$ as the dominant and reliable indicators for evaluating $\mathrm{P}$ transformation within aggregates under conservation agriculture based practices.

\section{Introduction}

Soils play an essential part in maintaining agroecosystem productivity and understanding the impacts of management practices for agricultural sustainability (Kibblewhite et al., 2008; Lavelle et al., 2014). Tillage and residue management practices under intensive tillage and residue burning agricultural practices improved soil structure, associated protection of SOM and biological activities (Sharma et al., 2019; Saikia et al., 2019a, b), which eventually improves organic matter, soil aggregation, and nutrient cycling in agricultural systems (Lal 1993; Montgomery 2007; Barrios 2007). Phosphorus (P), being the second most imperative nutrient, less available to plants due to its adsorption and precipitation with iron, aluminum and calcium in soils, thereby resulting in the rapid formation of non-labile P forms (Priyadarshi et al., 2018; Ahmed et al., 2019). Soil P transformations vary depending upon the soil type and management practices (Sharma et al., 2014). Moreover, the continuous application of phosphate fertilizers has led to the serious environmental threats including acidification, hardening and P leaching from the soil (Rigo et al., 2019). The sustainability of conventional RWS based on intensive tillage is threatened by scarcity of water, energy and labour, higher production cost and environmental pollution due to burning of crop residues and deteriorating soil health (Montgomery 2007; Srinivasan et al., 2012; Chauhan et al., 2012) and emerging challenges associate with climate change (Jat et al., 2016; Grant and Flaten 2019). To address the aforementioned issues, conservation agriculture (CA)-based practices (minimum tillage, residue retention and crop diversification) are being developed and promoted for rice and wheat production (Gathala et al., 2013). The alternative systems of tillage, green manure (GM) and residue management practices under CA-based practices can potentially lead to significant changes in the availability of nutrients in RWS (Bera et al., 2017; Saikia et al., 2019a). The CA-based practices holds the potential to enhance $\mathrm{P}$ availability by altering the soil microbial diversity and enzyme activity, which in turn affects the availability of soil P (Wang et al., 2011; Bhan and Behera 2014; Bezerra et al., 2015). These practices can increase the soil organic matter (SOM), carbon (C) sequestration, soil aggregation (Sithole et al., 2019) and contribute to higher crop yields (Xu et al., 2019).

Soil aggregate size, distribution and stability performs a important role in enhancing the physico-chemical and biological processes in soil (Jiao et al., 2006), and also affects the P forms and availability (Castro-Filho et al., 2002). The organic phosphorus $\left(P_{0}\right)$ is usually found in chemically or physically protected forms, which are mineralized slowly into available forms for plant uptake, mostly as a byproduct of SOM decomposition or through the action of specific enzymes. The constant loss of $P$ reservoir in the soil owing to crop harvesting, runoff and leaching can also consume $\mathrm{P}_{\mathrm{o}}$ and $\mathrm{P}_{\mathrm{i}}$ forms rapidly, and thus resulting in the deficiency of $\mathrm{P}$ to plant. This $\mathrm{P}$ loss is directly associated with the stability of soil aggregates and nutrients distribution within aggregates (Liu et al., 2010). The $P$ distribution among various fractions provides an indication of the potential stability of $P$ in soil which may vary with different management practices. In addition, stable aggregates reduce soil erosion and degradation, surface runoff and crusting (Sithole et al., 2019). Additionally, these CA-based practices comprising ZT with crop residues 
retention enhances soil aggregation, mean weight diameter of water-stable aggregates and also increases the resistance of aggregates to slaking (Sharma et al., 2019). We hypothesized that tillage, GM and residue management practices may lead to significant changes in P-fractions in soil aggregates. Furthermore, the focus was to elucidate the distribution of different fractions of $P\left(P_{i}\right.$ and $\left.P_{0}\right)$ in the aggregates and how these fractions affected the crop yield under CA-based RWS.

\section{Materials And Methods}

\subsection{Site description}

A field experiment (5-year) on irrigated RWS was initiated in 2011 with rice crop on a sandy loam soil classified as Typic Ustochrept (USDA classification) at the research farm of the Punjab Agricultural University, Ludhiana, Punjab $\left(30^{\circ} 56^{\prime} \mathrm{N}, 75^{\circ} 52^{\prime} \mathrm{E}\right.$, 247m ASL) Punjab, India.

The electrical conductivity, pH (1:2 soil: water), oxidizable carbon (SOC) (Walkley \& Black's, 1934), Oavialable-P (Olsen et al.,, 1954) and avialable-K (Jackson, 1967) content of $0-15 \mathrm{~cm}$ layer of soil was $0.34 \mathrm{dS} \mathrm{m}^{-1}, 7.81,3.51 \mathrm{~g} \mathrm{~kg}^{-1}, 11.3 \mathrm{mg} \mathrm{P} \mathrm{kg}^{-1}, 46.3$ $\mathrm{mg} \mathrm{K} \mathrm{kg}^{-1}$, respectively as explained in Saikia et al., (2019b). The region is characterized by a sub-tropical semi-arid type of climate with a hot summer (March-June), wet monsoon season (late June-mid September) and a very cold winter (OctoberFebruary). There were four main plot treatment combinations of wheat straw and Sesbania green manure management in rice (PTR $_{\text {Wo, }}$, puddled transplanted rice with no wheat straw; PTR $\mathrm{W}_{25}$, puddled transplanted rice with $25 \%$ anchored wheat stubbles retained; $\mathrm{PTR}_{\mathrm{W} 0}$ plus green manure, and $\mathrm{PTR}_{\mathrm{W} 25}$ plus green manure). The treatments in subplot consisted of three combinations of tillage and residue management in subsequent wheat $\left(C T W_{R 0}\right.$, conventional tilled wheat with rice residue removed; $Z T W_{R O}$, zero tilled wheat with rice residue removed and $Z \mathrm{ZTW}_{\mathrm{R} 100}$, zero tilled wheat with $100 \%$ rice residue retained as mulch). Full details experimental information is provided in Saikia et al (2019a) and only details relevant to the present study are discussed here (Table 1). 
Table 1

Description of treatments

\begin{tabular}{|c|c|c|}
\hline Abbreviation & Treatment detail & Method of crop establishment \\
\hline \multicolumn{3}{|c|}{ A. Rice (main plot treatments) } \\
\hline $\mathrm{PTR}_{\mathrm{W} 0}$ & $\begin{array}{l}\text { Conventional till } \\
\text { puddled } \\
\text { transplanted rice } \\
\text { (PTR) with wheat } \\
\text { straw removed } \\
\left(\mathrm{W}_{0}\right)\end{array}$ & $\begin{array}{l}\text { Residue of preceding wheat was removed. Pre- puddling tillage operations included } \\
\text { two discings and two harrowings followed by plankings. Puddling (wet tillage) was } \\
\text { done twice in } 6-8 \mathrm{~cm} \text { of standing water using a tractor-mounted puddler followed by } \\
\text { planking. Rice seedlings were manually transplanted at } 15 \times 20 \mathrm{~cm} \text { spacing }\end{array}$ \\
\hline $\mathrm{PTR}_{\mathrm{W} 25}$ & $\begin{array}{l}\text { PTR with anchored } \\
\text { wheat straw }\left(\mathrm{W}_{25}\right)\end{array}$ & $\begin{array}{l}\text { Anchored }(10-12 \mathrm{~cm} \text { high) wheat straw }(25 \%) \text { of preceding wheat was retained. All the } \\
\text { tillage and rice crop establishment operations were same as in } \mathrm{PTR}_{\mathrm{W} 0}\end{array}$ \\
\hline $\mathrm{PTR}_{\mathrm{WO}}+\mathrm{GM}$ & $\begin{array}{l}\text { PTR with green } \\
\text { manure (GM) }\end{array}$ & $\begin{array}{l}\text { Residue of preceding wheat was removed and zero till Sesbania green manure after } \\
\text { wheat harvest. Green manure was chopped by two discings and then incorporated } \\
\text { using two harrowings followed by planking. Puddling and rice establishment } \\
\text { operations were same as in PTR } \mathrm{R}_{\mathrm{W}}\end{array}$ \\
\hline $\mathrm{PTR}_{\mathrm{W} 25}+\mathrm{GM}$ & $\begin{array}{l}\text { PTR with anchored } \\
\text { wheat straw + } \\
\text { green manure }\end{array}$ & $\begin{array}{l}\text { Anchored wheat residue of preceding wheat was retained and zero till Sesbania green } \\
\text { manure was sown in standing stubbles. Green manure incorporation and puddling } \\
\text { operations were same as in PTR } \mathrm{R}_{\mathrm{W}}+\mathrm{GM} \text {. Rice seedlings were manually transplanted at } \\
15 \times 20 \mathrm{~cm} \text { spacing }\end{array}$ \\
\hline \multicolumn{3}{|c|}{ B. Wheat (sub-plot treatments) } \\
\hline $\mathrm{CTW}_{\mathrm{RO}}$ & $\begin{array}{l}\text { Conventional till } \\
\text { wheat (CTW) after } \\
\text { removal of rice } \\
\text { residue }\end{array}$ & $\begin{array}{l}\text { All the residue of previous rice crop was removed. Tillage operations included two } \\
\text { passes of harrows and two passes of tine plough followed by plankings. After pre- } \\
\text { sowing irrigation, seed bed was prepared by two passes of tine plough followed by } \\
\text { planking. Wheat was sown using seed cum fertilizer drill in rows } 20 \mathrm{~cm} \text { apart }\end{array}$ \\
\hline $\mathrm{ZTW}_{\mathrm{RO}}$ & $\begin{array}{l}\text { Zero till wheat } \\
\text { (ZTW) after } \\
\text { removal of rice } \\
\text { residue }\end{array}$ & $\begin{array}{l}\text { Residue of previous rice crop was removed. Wheat was direct seeded in the no till plots } \\
\text { in rows } 20 \mathrm{~cm} \text { apart using zero till seed cum fertilizer drill. }\end{array}$ \\
\hline $\mathrm{ZTW}_{\mathrm{R} 100}$ & $\begin{array}{l}\text { Zero till wheat with } \\
100 \% \text { rice residue } \\
\text { as mulch }\end{array}$ & $\begin{array}{l}\text { Residue of previous rice crop was retained. Wheat was direct seeded in rows } 20 \text { cm } \\
\text { apart into rice residues using Turbo Happy Seeder (Sidhu et al. 2015). }\end{array}$ \\
\hline
\end{tabular}

\subsection{Soil analysis}

Undisturbed soil clods measuring about $50 \mathrm{~cm}$ in diameter from the soil layer $(0-15 \mathrm{~cm})$ were collected from each plot in duplicate after wheat harvest (after seven cycles of RWS) using hand shovels for analysis of aggregate size and different fractions of P. After shade drying, soil clods were left to fall from waist height on to a grassy surface to naturally break at of cleavage.

\subsection{Soil physical characteristics}

For aggregate analysis, the samples were passed through a $4.0 \mathrm{~mm}$ sieve. The aggregates retained over a $2.0 \mathrm{~mm}$ sieve were retained for aggregate size analysis. A nest of six sieves $(2.0,1.0,0.50,0.25,0.11$ and $0.053 \mathrm{~mm})$ were used for wet sieving of aggregate (Yoder, 1936) and weighed each sieve after drying. The aggregate samples were collected from sieves $2 \mathrm{~mm}, 1-2 \mathrm{~mm}$, below $0.25 \mathrm{~mm}$ for micro-aggregates and above $0.25 \mathrm{~mm}$ sieves for macro-aggregates and above using the sequential extraction procedure as given by Sui et al., (1999) was employed for P fractionation studies (Fig. 1). Total P in the samples was analyzed by the method given by Alexander and Robertson (1968). Available P was estimated using the methods described by Olsen et al., (1954) by using $0.5 \mathrm{~N} \mathrm{NaHCO}_{3}(\mathrm{pH} 8.5)$ as extracting agent. The intensity of blue color was directly proportional to the P content in soil was read on a colorimeter at a wavelength of $660 \mathrm{~nm}$. The alkaline phosphatase (Alk-P EC 3.1.3.1) activity was assayed on the basis of p-nitrophenol (pNP) release after cleavage of enzyme-specific synthetic substrates (Tabatabai and Bremner 1969). This is based on the colorimetric estimation of the $\mathrm{p}$-nitrophenol released when soil is incubated with buffered ( $\mathrm{pH} 11)$ 
sodium p-nitrophenyl phosphate solution. The phytin P was estimated by extraction of phytate with $15 \% \mathrm{CCl}_{3}$ - $\mathrm{COOH}$ (trichloroacetic acid) as described by Mega (1982).

\subsection{Statistical analysis}

The data were statistically analyzed using analysis of variance technique in split plot design using CPCS1, locally developed software (Cheema and Singh 1990). Mean separation for different treatments was performed using the Least Significant Difference (LSD) test. Differences in treatments on for dif $p<0.05$ were considered statistically significant. The principal component analysis (PCA) method is statistical tool to avoid any biasness (Wold et al., 1987). The soil quality index (SQI) was calculated using integrated score and weight factor of each indicator using equation (Andrews et al.,,2002)

Soil quality index (SQI) $=\sum_{i=1}^{n} W_{i} \times S_{i}$

Where, ' $\mathrm{S}$ ' = indicator score and $\mathrm{W}=$ PCs weight factor

\section{Results}

\subsection{Aggregate-associated inorganic and organic $\mathrm{P}$ fractions}

The tillage, GM and residue management practices in the present study had posed significant effects on the $\mathrm{P}$ fractions across different sized aggregates (Fig. 2-3). In the micro-aggregates fraction ( $<0.25 \mathrm{~mm}$ ), the water soluble phosphorus (WS-P) in PTR $_{W 25}+$ GM was significantly 29.2, 39.0, and 82.9\% higher than PTR ${ }_{W 0}+G M, P^{2} R_{W 25}$ and PTR ${ }_{W 0}$, respectively. Likewise, for other

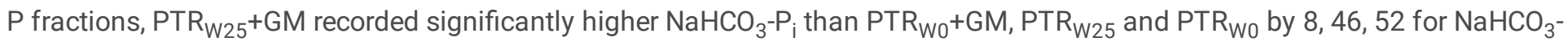
$\mathrm{P}_{\mathrm{i}} ; \mathrm{NaHCO}_{3}-\mathrm{P}_{\mathrm{o}}$ by $7.4,27.5,49.4 \%$ and $\mathrm{NaOH}-\mathrm{P}_{\mathrm{i}}$ by $22.5,5.5,22.5 \%$, respectively. In contrast to the above fractions, the significantly highest levels of $\mathrm{NaOH}$ extractable $\mathrm{P}_{\mathrm{o}}\left(13.6 \mathrm{mg} \mathrm{kg}^{-1}\right)$ were obtained in treatment PTR $\mathrm{WO}_{0}+\mathrm{GM}$. Moreover, the HCl-P was the dominant $\mathrm{P}$-fraction, followed by $\mathrm{NaHCO}_{3}-\mathrm{P}$. In contrast to other P-fractions, the maximum $\mathrm{HCl}-\mathrm{P}$ in aggregate size $<0.25$ $\mathrm{mm}(\mathrm{p}<0.004)$ and $>0.25 \mathrm{~mm}(\mathrm{p}<0.03)$ was recorded in treatment PTR $\mathrm{W}_{25}+\mathrm{GM}$ followed by PTR $\mathrm{WO}_{\mathrm{O}}+\mathrm{GM}$, respectively. Similar results were observed for the relative distribution of $P$ under aggregate size $>0.25,1-2$ and $>2 \mathrm{~mm}$.

Among tillage and residue retention practices in wheat, $\mathrm{ZTW}_{\mathrm{R} 100}$ resulted in the significantly higher $\mathrm{P}$ concentration in all the inorganic and organic P-fractions (WS-P, $\mathrm{NaHCO}_{3}-\mathrm{P}_{0}, \mathrm{NaHCO}_{3}-\mathrm{P}_{\mathrm{i}}, \mathrm{NaOH}-\mathrm{P}_{\mathrm{O}}, \mathrm{NaOH}-\mathrm{P}_{\mathrm{i}}$ and $\mathrm{HCl}-\mathrm{P}$ ) across different aggregate size compared with $\mathrm{ZTW}_{\mathrm{RO}}$ and $\mathrm{CTW}_{\mathrm{RO}}$ (Fig. 2-3). The HCl-P was found to be dominant fractions which was increased significantly under $\mathrm{ZTW}_{\mathrm{R} 100}$ by 13.3 and $35.9 \% ; 18.4$ and $30.2 \% ; 7.3$ and $32.8 \%$ and 25.7 and $47.5 \%$ in $<0.25 \mathrm{~mm},>0.25 \mathrm{~mm}, 1-2 \mathrm{~mm}$ and $>2$ $\mathrm{mm}$ size aggregates compared with $\mathrm{ZTW}_{\mathrm{R} 0}$ and $\mathrm{CTW}_{\mathrm{RO}}$, respectively. Hence, the comparison of various $\mathrm{P}$ fractions within different aggregate size classes revealed significantly higher concentration of $\mathrm{P}$ in $\mathrm{PTR}_{\mathrm{W} 25}+\mathrm{GM}$ and $\mathrm{ZTW}_{\mathrm{R} 100}$.

\subsection{Soil total, available and alkaline $P$}

The distribution of $\mathrm{P}_{\mathrm{i}}$ and $\mathrm{P}_{\mathrm{o}}$ fractions within different aggregate classes showed maximum total $\mathrm{P}$ in the aggregate size 1-2 mm followed by $>2 \mathrm{~mm}$ (macro-aggregates) then $>0.25 \mathrm{~mm}$ and least in the $<0.25 \mathrm{~mm}$ (micro-aggregates) (Fig. 4). The average total

$\mathrm{P}$ ranged from $84.8-135.0 \mathrm{mg} \mathrm{kg}^{-1}$ with the highest observed in the treatment PTR $\mathrm{W}_{25}+\mathrm{GM}$ followed by PTR $\mathrm{W}_{0}+\mathrm{GM}_{1} \mathrm{PTR} \mathrm{R}_{\mathrm{W} 25}$ and $\mathrm{PTR}_{\mathrm{W}_{0} \text {. Compared to the PTR }}$ and PTR $\mathrm{W}_{\mathrm{W} 25}$ treatments, the PTR $\mathrm{W}_{25}+\mathrm{GM}$ increased the soil total $\mathrm{P}$ by $59.2 \%$ and $27.7 \%$, respectively, in the fraction 1-2 mm. Thus, the total $P$ in aggregate fraction 1-2 mm accounted for the major $P$ proportion (130 $\left.\mathrm{mg} \mathrm{kg}^{-1}\right)$, consistent with the overall distribution of aggregates under various treatments. Among the tillage and residue management practices in wheat, $\mathrm{ZTW}_{\mathrm{R} 100}$ accumulates the significantly higher total P over ZTW $\mathrm{R}_{\mathrm{R}}$ and CTW $\mathrm{R}_{\mathrm{R}}$, in macro- as well as micro-aggregates. Here also, the aggregate size 1-2 mm possessed the maximum total $\mathrm{P}$ compared to other aggregate size particles.

The available-P was also highest in aggregate size, 1-2 $\mathrm{mm}$ followed by $>2 \mathrm{~mm}$ then $>0.25 \mathrm{~mm}$ while least was observed in < $0.25 \mathrm{~mm}$ (Fig. 5). The average available-P was recorded to be the significantly higher in $\mathrm{PTR}_{\mathrm{W} 25}+\mathrm{GM}$ by $12.2 \%, 18.0 \%$ and $20.4 \%$ compared with $\mathrm{PTR}_{\mathrm{W}_{0}}+\mathrm{GM}, \mathrm{PTR}_{\mathrm{W} 25}$, and PTR $\mathrm{W}_{\mathrm{W}}$, respectively. Consistent with the results of total $\mathrm{P}$, the $\mathrm{ZTW}_{\mathrm{R} 100}$ treatment also 
exhibited significantly higher the available $P$ by 32.5 and $13.3 \%$ in $<0.25 \mathrm{~mm}$ size, 7.4 and $10 \%$ in the $>0.25 \mathrm{~mm}$ size, by 18.7 and $13.1 \%$ in the $1-2 \mathrm{~mm}$ and by 15.3 and $5.8 \%$ in the $>2 \mathrm{~mm}$ over $\mathrm{ZTW}_{\mathrm{RO}}$ and $\mathrm{CTW}_{\mathrm{RO}}$, respectively.

Among rice treatments, higher alkaline phosphatase activity and phytin-P content were observed in the treatment PTR $\mathrm{R}_{\mathrm{W} 25}+\mathrm{GM}$ which were 2.5 and $4.2 \%$ higher than $\mathrm{PTR}_{\mathrm{W}_{0}}+\mathrm{GM}, 20.6$ and $20.7 \%$ than $\mathrm{PTR}_{\mathrm{W} 25}$ and 54.1 and $22.6 \%$ than PTR $\mathrm{W}_{\mathrm{W}}$, respectively (Fig. 6-7). In both the aggregate fractions $(<0.25 \mathrm{~mm}$ and $>0.25 \mathrm{~mm}$ ), significantly higher alkaline phosphatase activity $(p<$ $0.05)$ and phytin-P $(p<0.05)$ content were recorded in treatment $P T R_{W 25}+G M$. The macro-aggregate fraction contributed higher towards the enzyme activity and phytin-P content than in micro-aggregate. In wheat treatments, when $100 \%$ rice residue was incorporated along with GM in ZT wheat, the alkaline phosphatase activity and phytin-P content were highest irrespective of the type of fraction (Fig. 6). The average activity varied from 59.3 to $82.0 \mu \mathrm{gNPg}^{-1} \mathrm{~h}^{-1}$ and 25.98 to $21.65 \mathrm{mg} \mathrm{kg}^{-1}$ in the $\mathrm{ZTW}_{\mathrm{R} 100}$, $\mathrm{ZTW}_{\mathrm{R} 0}$ and $C T W_{\mathrm{RO}}$, respectively. Thus, our results indicated that among the different sized fractions, 1-2 mm possessed maximum available $\mathrm{P}$, total $\mathrm{P}$ and alkaline phosphatase activity and phytin-P content compared with other aggregate size particles.

\subsection{Crop yield and nutrient uptake}

Conservation agriculture based practices in rice significantly affected the grain yield (Figure or Table 2). The grain yield in PTR $_{\mathrm{W} 25}+\mathrm{GM}$ increased by $11 \%, 15 \%$ and $26 \%$ compared with $\mathrm{PTR}_{\mathrm{W} 0}+\mathrm{GM}, \mathrm{PTR}_{\mathrm{W} 25}$ and PTR $\mathrm{W}_{\mathrm{W}}$, respectively. Similarly, the tillage based crop establishment treatments in wheat significantly affected the grain yield, straw yield, grain and total P uptake (Table 3). The increase in grain yield under ZT along with residue retention was $19 \%$ and $9 \%$ higher than ZT and CT without residue, respectively. Like grain yield, rice residue management practices showed higher effect on grain yield attributes. The grains spike ${ }^{-}$

${ }^{1}$ was significantly higher under $\mathrm{ZTW}_{\mathrm{R} 100}$ than that of $\mathrm{ZTW}_{\mathrm{R} 0}$. Grain yields of wheat were significantly related to total $\mathrm{P}$ and $\mathrm{NaOH}-\mathrm{Po}$ fraction $\left(r=0.997^{\star *}\right.$ and $0.988^{\star}$, respectively, $\left.\mathrm{p}<0.05\right)$ (Table 4$)$. The available $\mathrm{P}$ and alkaline phosphatase activity also exhibited significant relationships with wheat grain $\left(r=0.968^{\star *}\right.$ and $0.949 * \star$, respectively, $\left.p<0.05\right)$. 
Table 2

Yield and yield attributes of wheat in affected by treatments applied to rice and wheat

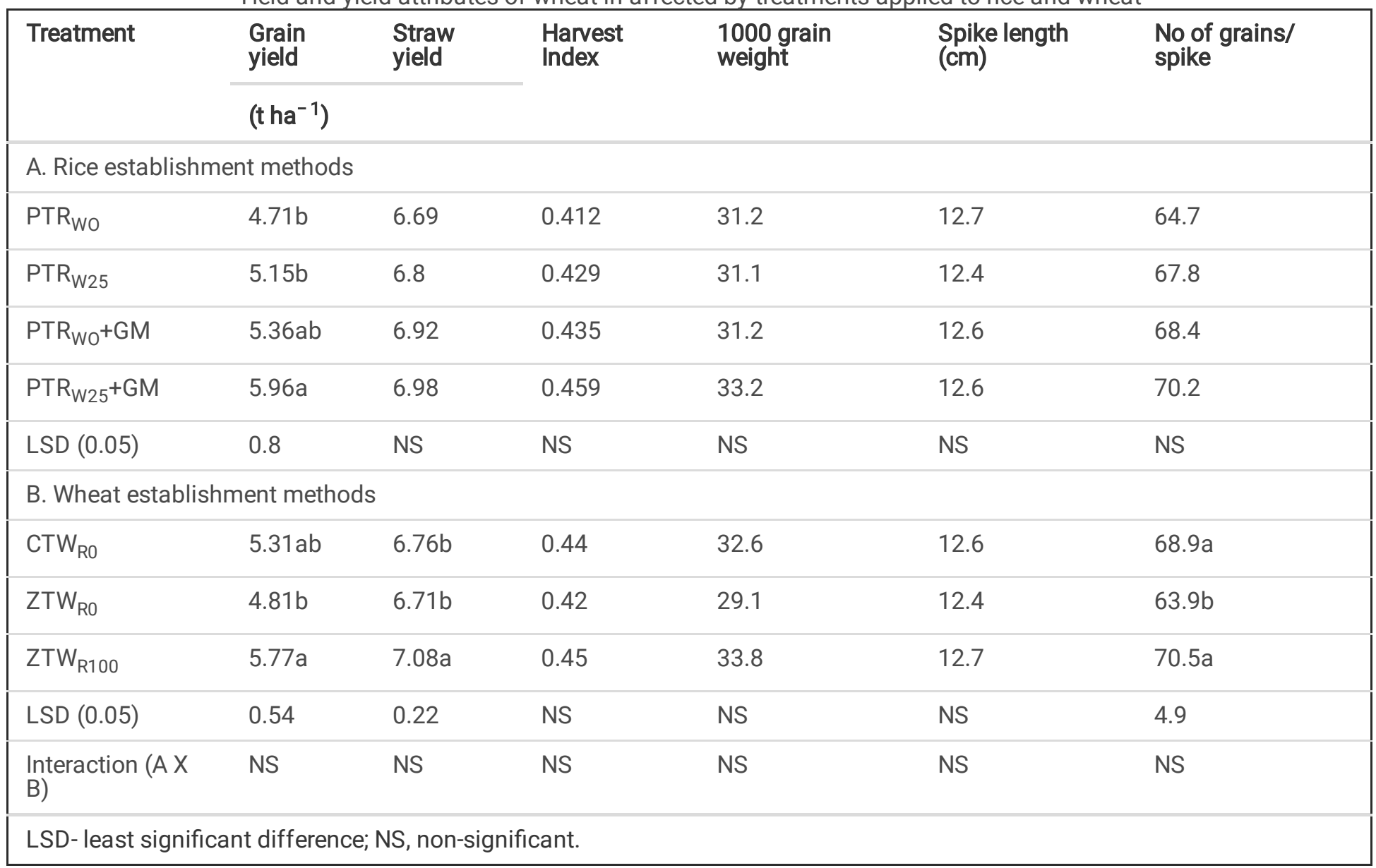


Table 3

Effect of tillage, green manure and residue management practices on phosphorus content and uptake in wheat after five years of rice-wheat cropping system

\begin{tabular}{|c|c|c|c|c|c|c|}
\hline \multirow[t]{2}{*}{ Treatments } & \multirow{2}{*}{$\begin{array}{l}P \text { in grain } \\
(\%)\end{array}$} & \multirow{2}{*}{$\begin{array}{l}P \text { in straw } \\
(\%)\end{array}$} & P uptake by grain & P uptake by straw & Total P uptake & PHI \\
\hline & & & \multicolumn{4}{|l|}{$\left(\mathrm{Kg} \mathrm{ha}^{-1}\right)$} \\
\hline \multicolumn{7}{|c|}{ A. Rice establishment methods } \\
\hline \multicolumn{7}{|l|}{ PTR $_{\text {Wo }}$} \\
\hline PTR $_{\text {W25 }}$ & 0.31 & 0.027 & 15.7 & 1.86 & 17.5 & 0.89 \\
\hline $\mathrm{PTR}_{\mathrm{WO}}+\mathrm{GM}$ & 0.3 & 0.033 & 16 & 2.28 & 18.3 & 0.97 \\
\hline $\mathrm{PTR}_{\mathrm{W} 25}+\mathrm{GM}$ & 0.28 & 0.034 & 16.7 & 2.39 & 19 & 0.87 \\
\hline LSD (0.05) & NS & NS & NS & NS & NS & NS \\
\hline \multicolumn{7}{|c|}{ B. Wheat establishment methods } \\
\hline $\mathrm{CTW}_{\mathrm{R} 0}$ & 0.28 & 0.03 & $14.8 \mathrm{ab}$ & 2.07 & $16.9 \mathrm{~b}$ & 0.87 \\
\hline $\mathrm{ZTW}_{\mathrm{R} 0}$ & 0.29 & 0.029 & $13.8 b$ & 1.96 & $15.8 \mathrm{~b}$ & 0.87 \\
\hline $\mathrm{ZTW}_{\mathrm{R} 100}$ & 0.3 & 0.035 & $17.7 a$ & 2.49 & $20.2 a$ & 0.87 \\
\hline LSD (0.05) & NS & NS & 3.2 & NS & 3.1 & NS \\
\hline Interaction (AX B) & NS & NS & NS & NS & NS & NS \\
\hline
\end{tabular}


Table 4

Pearson's correlation coefficients ( $r$ ) between phosphorus fractions, biological activity and crop yield

\begin{tabular}{|c|c|c|c|c|c|c|c|c|c|c|c|}
\hline Variable & WS-P & $\begin{array}{l}\mathrm{NaHCO}_{3}- \\
\mathrm{Pi}\end{array}$ & $\begin{array}{l}\mathrm{NaHCO}_{3}- \\
\mathrm{Po}\end{array}$ & $\begin{array}{l}\mathrm{NaOH}- \\
\mathrm{Pi}\end{array}$ & $\begin{array}{l}\mathrm{NaOH}- \\
\mathrm{Po}\end{array}$ & HCl-P & TP & Av-P & Alk-p & Phy-P & Yield \\
\hline WS-P & 1 & & & & & & & & & & \\
\hline $\begin{array}{l}\mathrm{NaHCO}_{3}^{-} \\
\mathrm{Pi}\end{array}$ & $0.992^{\star \star}$ & 1 & & & & & & & & & \\
\hline $\begin{array}{l}\mathrm{NaHCO}_{3}^{-} \\
\text {Po }\end{array}$ & $0.954^{\star \star}$ & $0.967^{\star \star}$ & 1 & & & & & & & & \\
\hline $\mathrm{NaOH}-\mathrm{Pi}$ & $0.868^{\star}$ & $0.833^{*}$ & $0.865^{\star}$ & 1 & & & & & & & \\
\hline $\begin{array}{l}\mathrm{NaOH}- \\
\mathrm{PO}\end{array}$ & $0.930^{\star \star}$ & $0.921^{\star \star}$ & $0.959^{\star \star}$ & $0.942^{\star \star}$ & 1 & & & & & & \\
\hline $\mathrm{HCl}-\mathrm{P}$ & $0.761^{*}$ & 0.752 & 0.718 & $0.835^{\star}$ & 0.718 & 1 & & & & & \\
\hline TP & $0.975^{\star \star}$ & $0.966^{\star \star}$ & $0.972^{\star \star}$ & $0.943^{\star \star}$ & $0.984^{\star \star}$ & $0.793^{*}$ & 1 & & & & \\
\hline$A v-P$ & $0.935^{\star \star}$ & $0.944^{\star *}$ & $0.964^{\star \star}$ & $0.842^{*}$ & $0.970^{\star \star}$ & 0.608 & $0.957^{\star \star}$ & 1 & & & \\
\hline Alk-P & $0.979^{\star \star}$ & $0.985^{\star \star}$ & $0.932^{\star \star}$ & $0.786^{*}$ & $0.904^{\star \star}$ & 0.668 & $0.940^{\star *}$ & $0.950^{\star \star}$ & 1 & & \\
\hline Phy-P & $0.972^{\star \star}$ & $0.965^{\star \star}$ & $0.909^{\star \star}$ & $0.878^{\star \star}$ & $0.881^{\star \star}$ & $0.865^{\star}$ & $0.950^{\star \star}$ & $0.864^{*}$ & $0.929^{\star \star}$ & 1 & \\
\hline Yield & $0.972^{\star \star}$ & $0.962^{\star \star}$ & $0.963^{\star \star}$ & $0.934^{\star \star}$ & $0.988^{\star \star}$ & $0.765^{\star}$ & $0.997^{\star \star}$ & $0.968^{\star \star}$ & $0.949^{\star \star}$ & $0.937^{\star \star}$ & 1 \\
\hline \multicolumn{12}{|c|}{ *,**Significant at 0.05 and 0.01 probability level, respectively. } \\
\hline \multicolumn{12}{|c|}{ 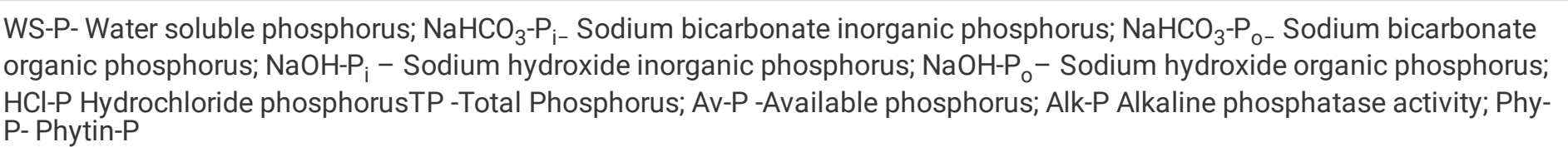 } \\
\hline
\end{tabular}

\subsection{Principal component analysis}

Principal component analysis was performed to extract most influential soil parameters from each PC on the basis of eigenvector weight value or loading factors (Table 5). Only the highly weighted variables were retained in the minimum data set (MDS). The PC1 and PC2 explained 88.0\% variability in the data set, where PC1 explained $74.68 \%$ and PC2 explains $13.32 \%$. Hence, the bold-face values ( $\mathrm{NaOH}-\mathrm{P}_{\mathrm{O}}$ and $\mathrm{NaHCO}_{3}-\mathrm{P}_{\mathrm{i}}$ for $\mathrm{PC} 1, \mathrm{HCl}-\mathrm{P}$ for PC2) were considered to be highly weighted eigen vectors and were initially selected in the MDSThe amount of variability explained by PC1 was $74.7 \%$, with eigenvalue of 7.47 , which includes $\mathrm{NaOH}-\mathrm{P}_{0}$, with the highest positive factor loading value (0.95), and $\mathrm{NaHCO}_{3}-\mathrm{P}_{\mathrm{i}}(0.93)$ (Table 5). The component PC2 explained variance of about $13.3 \%$ and eigenvalue of 1.33 with the highest positive loading value for $\mathrm{HCl}-\mathrm{P}$ with positive factor loading (0.78). Based on the percent variance to total variance, the weight of each PC ranged from 0.15 to 0.85. 
Table 5

Loading values and percent contribution of assayed soil variables at surface soil layer on the axis identified by the principal component analysis

\begin{tabular}{|c|c|c|c|c|}
\hline Soil variables & PC1 & & PC2 & \\
\hline & Loading value & $\begin{array}{l}\text { Contribution of } \\
\text { variables (\%) }\end{array}$ & Loading value & $\begin{array}{l}\text { Contribution of } \\
\text { variables (\%) }\end{array}$ \\
\hline WS-P & 0.864 & 9.99 & 0.425 & 13.6 \\
\hline $\mathrm{NaHCO}_{3}-\mathrm{P}_{\mathrm{i}}$ & 0.934 & 11.7 & -0.123 & 1.13 \\
\hline $\mathrm{NaHCO}_{3}-\mathrm{P}_{\mathrm{o}}$ & 0.875 & 10.2 & 0.311 & 7.25 \\
\hline $\mathrm{NaOH}-\mathrm{P}_{\mathrm{i}}$ & 0.911 & 11.1 & -0.308 & 7.11 \\
\hline $\mathrm{NaOH}-\mathrm{P}_{\mathrm{o}}$ & 0.950 & 12.1 & -0.258 & 5.02 \\
\hline $\mathrm{HCl}-\mathrm{P}$ & 0.480 & 3.08 & 0.784 & 46.1 \\
\hline TP & 0.794 & 8.44 & 0.192 & 2.75 \\
\hline Av-P & 0.885 & 10.5 & -0.417 & 13.0 \\
\hline Alk-P & 0.922 & 11.4 & -0.225 & 3.81 \\
\hline Phytin P & 0.926 & 11.5 & 0.054 & 0.22 \\
\hline Eigenvalue & & 7.47 & & 1.33 \\
\hline Variability (\%) & & 74.7 & & 13.3 \\
\hline Cumulative \% & & 74.7 & & 88.0 \\
\hline weight & & 0.85 & & 0.15 \\
\hline
\end{tabular}

Position of different variables and treatments in the orthogonal space were defined by the two PCs (Fig. 8). The first principal component clearly separated $<0.25 \mathrm{~mm}$ and $>0.25 \mathrm{~mm}$ size aggregates from $1-2 \mathrm{~mm}$ and $>2 \mathrm{~mm}$ size aggregates. It also clearly separated PTR $\mathrm{w} 25+\mathrm{GM}$ and PTR $\mathrm{W}_{0}+\mathrm{GM}$ from PTR $\mathrm{W}_{0}$ and PTR $\mathrm{W}_{25}$ treatment and $\mathrm{ZTW}_{\mathrm{R} 100}$ treatments from $\mathrm{ZTW}_{\mathrm{R} 0}$ and $\mathrm{CTW}_{\mathrm{RO}}$ treatments in the factorial space. The variables $\left(\mathrm{NaOH}-\mathrm{Po}, \mathrm{NaHCO}_{3}-\mathrm{P}_{\mathrm{i}}\right.$ and $\left.\mathrm{HCl}-\mathrm{P}\right)$ are related to the large size aggregates (both $2 \mathrm{~mm}$ and $>2 \mathrm{~mm}$ ). These variables are also found to be related to $P T R_{W 25}+G M, P T R_{W 0}+G M$ and $Z T W_{R 100}$ treatments. The results displayed that the contribution of $\mathrm{NaOH}-\mathrm{P}_{\mathrm{O}}$ toward SQI was highest under $\mathrm{PTR}_{\mathrm{W} 25}+\mathrm{GM}(0.643)$ followed by PTR $\mathrm{W}_{\mathrm{W} 25}$ (0.508) in rice treatments and $\mathrm{CTW}_{\mathrm{RO}}(0.584)$ followed by ZTW $\mathrm{R} 100(0.589)$ in wheat treatments (Fig. 9). For $\mathrm{NaHCO}_{3}-\mathrm{P}_{\mathrm{i}}$ the maximum contribution toward SQI was observed under PTR $\mathrm{W}_{25}+\mathrm{GM}(0.710)$ followed by $\mathrm{PTR}_{\mathrm{W}_{0}}(0.659)$ in rice treatments and ZTW $_{\mathrm{R} 100}(0.711)$, followed by CTW $R 0$ (0.701) in wheat treatments. The HCl-P contributed maximum to SQI under PTR W25 + GM (0.137) in rice treatments and $Z \mathrm{ZTW}_{\mathrm{R} 100}(0.145)$ followed by $\mathrm{CTW}_{\mathrm{R} 0}(0.136)$ in wheat treatments. The relative order of contribution of the selected indicators to SQI was $37.2 \%$ for $\mathrm{NaOH}-\mathrm{P}_{0}, 48.8 \%$ for $\mathrm{NaHCO}_{3}-\mathrm{P}_{\mathrm{i}}$ and, and $9.1 \%$ for $\mathrm{HCl}-\mathrm{P}$ (Fig. 10). The radar plot represented the specific contribution of MDSs toward SQI. $\mathrm{NaHCO}_{3}-\mathrm{P}_{\mathrm{i}}$ had the highest MSDs (49.3-61.6), HCl-P (6.9-12.8-16.4) had the lowest, whilst $\mathrm{NaOH}-\mathrm{P}_{\mathrm{o}}(25.6-42.7)$ in-between for residue retention and green manure CA-based RWS (Fig. 11).

\section{Discussion}

\subsection{Particle size phosphorus fractions in aggregates}


Retention of crop residue promotes microbial activity which enhances the aggregates cohesion and hydrophobicity (Wallis and Horne 1992). Hangen et al., (2002) reported the destruction of soil macro-pores in conservation tillage and further reduction in the loss of dissolved $\mathrm{P}$ through leaching. In the present study, the comparison of $\mathrm{P}$-fractions among different aggregate size indicated that PTR $\mathrm{W}_{25}+\mathrm{GM}$ and $\mathrm{ZTW} \mathrm{R}_{\mathrm{R} 100}$ recorded the highest P-forms under CA-based RWS. Also, the application of green manure and crop residue management practices has resulted in enhanced $P$ content predominantly " $n$ aggregate size 1-2 mm relative to other sized aggregates. This may be probably because smaller aggregates possess larger surface area, higher $\mathrm{P}$ sorption, and hence less $\mathrm{P}$ availability. Whereas, larger soil aggregates have less surface area, reduced $\mathrm{P}$ fixation and enhanced $\mathrm{P}$ availability (Mitran et al., 2018). As defined by Verma et al., (2005) and Chimdi et al., (2014), the water extractable and $\mathrm{NaHCO}_{3}-\mathrm{P}$ $\left(\mathrm{P}_{\mathrm{i}}\right.$ and $\left.\mathrm{P}_{\mathrm{o}}\right)$ are considered as readily desorbable or labile phosphorus pools. This water soluble-P represent the readily available-P. The $\mathrm{NaHCO}_{3}$-Pi is the most biologically available inorganic $\mathrm{P}$ fraction and $\mathrm{NaHCO}_{3}-\mathrm{Po}$ is considered as the easily mineralized $\mathrm{P}$ fractions in the form of phospholipids and nucleic acid (Harrison, 1987). In our study, NaOH-P $\left(P_{i}\right.$ and $\left.P_{0}\right)$ fractions were observed to be higher in treatment PTR $\mathrm{W}_{25}+\mathrm{GM}$ and $\mathrm{ZTW}_{\mathrm{R} 100}$. Therefore, rice residue management practices are anticipated to have a positive impact on increasing $P$ availability which contributes towards increased crop yield (Sharma et al 2021). Moreover, the present results indicated the dominance of $\mathrm{HCl}-\mathrm{P}$ in all the aggregate size classes which is consistent with the results of Castillo and Wright (2008) who also observed the highest percentage of total P (41\%) in Ca-bound P fraction (HCl-P) for sugarcane. Our findings also corroborated with the previous results by Ranatunga et al., (2013), who observed that long-term poultry litter application in pasture soil recorded highest level of $\mathrm{HCl}-\mathrm{P}$ in 1-2 mm macro-aggregate. The $\mathrm{NaOH}-\mathrm{P}$ and $\mathrm{HCl}-\mathrm{P}$ are sparingly labile-P and on long-term basis, these forms might play an essential role in the in plant nutrition. The RWS in the current study indicated the dominance of organic phosphorus fractions which may be due to the degradation of organic $\mathrm{P}$ and release of inorganic $\mathrm{P}$ for plants. The increase in $\mathrm{P}$ concentration under $\mathrm{ZT}$ is consistent with previous tillage studies by Essington and Howard (2000) who observed significantly higher organic P in ZT than CT. Our results also indicated that the wheat stubble and green manure in rice exhibited increased total and available $\mathrm{P}$ concentrations in the macro-aggregate fractions. This might be due to the long-term addition of crop residue to soil, which increased the soil total phosphorus and available phosphorus contents (Ahmed et al., 2019). The ZT and residue retention might have increased the labile $P, P_{0}$ accumulation and its mineralization by phosphatases. A higher dissolved reactive P concentration in the leachate was reported by Gaynor and Findlay (1995) in ZT than CT. Previous studies have reported that ZT combined with straw retention, protects soil structure and aggregate-association $\mathrm{n}$ is an effective measure to improved soil structure soil fertility to increased higher yields (Xu et al., 2019; Sharma et al 2019).

\subsection{Soil alkaline phosphatase activity}

The alterations in the soil biological dynamics could be easily revealed by the variations in enzyme activities (Dick and Kandeler 2005). The mineralization of $P_{0}$ to available $P_{i}$ is driven by phosphatases in the soil (Nannipieri et al., 2011). Phosphatase enzymes play key roles in the soil system as good indicator of soil fertility (Dick and Tabatai 1992; Dick et al., 2000). The longterm crop residue management practices caused significant increase in microbial population and microbial biomass $\mathrm{C}$ or $\mathrm{N}$ in the soil (Gianfreda et al., 2005; Wei et al., 2015), and thus providing energy and a favorable environment for the accumulation of soil enzymes (Jiao et al., 2011). Gupta and Germida (1988) observed that the macro-aggregates had higher phosphatase activity in crop residues retention and ZT than CT in their respective micro-aggregates, which corresponds with the present results. The higher aggregate associated inorganic $\mathrm{P}$ in our study may be due to higher microbial proliferation resulting from the retention of crop residues, addition of GM and ultimately enhancing $\mathrm{P}_{\mathrm{o}}$ mineralization over time. Similar findings were also mentioned by Margenot et al., (2015), who determined increased alkaline phosphatase activity (41\%) under RT than CT. The highest activities of most of the enzymes under rice residue management practices in wheat are in agreement with the earlier findings of Sharma et al., (2019). They observed that higher enzyme activities are associated with macro-aggregates than micro-aggregates due to improvement of organic carbon status of soils under rice residue retention in wheat. Higher phytin-P content in ZTW $+\mathrm{R}$ may be due to higher build up of organic matter (Saikia et al., 2019a; Yadav and Tarafdar 2004) that resulted in increased release of $P$ from phytate present in the soil.

\subsection{Yield and nutrient uptake}


Significantly higher grain yield in treatments $P T R_{W_{0}}+G M$ and PTR $R_{W 25}+G M$ could be attributed to the addition of green manure which helps to enhance the availability of nutrients. Furthermore, the GM addition provides other essential nutritive substrates along with favorable conditions required for plants growth during the period of grain filling (Diez et al., 2010). Similarly, higher wheat yield was recorded under ZTwith residue retentioncompared with CT. This enhanced yield might be related with the improvement in soil physical properties and water retention especially under ZT with residue retention than CT for nutrient accessibility (Singh et al 2019). The present results were consistent with the findings of Zhang et al., (2013) who reported slight increase in the yields of rape and rice by the NT than CT across three years. Nandan et al., (2018) reported higher grain yield by the crop establishment practices based on ZT than $\mathrm{CT}$ in wheat and maize. The highest increase in productivity was recorded in maize $(7-10 \%)$, followed by wheat $(5-11 \%)$ and rice $(3-8 \%)$ by retention of crop residues. The wheat grain yield was significantly higher by $7.3 \%$ and $17.5 \%$ in ZT with residue retention in comparison with CT and ZT with no residue, respectively. Also, the $11.5 \%$ higher productivity was recorded in puddled transplanted rice with wheat stubble with GM followed by ZT with residue retention compared with CT under RWS (Thind et al., 2019). Significant increase in yield and macro-nutrients uptake in wheat and rice by tillage and rice-straw management practices was also reported by Sharma et al., (2019).

\subsection{Principal component analysis}

The alterations in the soil properties were represented by the PCs with higher eigen values (Zhang et al., 2016; Biswas et al., 2017) and for the interpretation, only PCs with eigen values $>1$ were retained (Ana et al., 2008). The data points for ZT are separated clearly from the data points for CT in the PCs defined factorial space (Fig. 8). The most influential variables for PC1 were $\mathrm{NaOH}$ $\mathrm{P}_{0}, \mathrm{NaHCO}_{3}-\mathrm{P}_{\mathrm{i}}$ and $\mathrm{HCl}-\mathrm{P}$ for $\mathrm{PC} 2$ on the basis of eigen vector weight value (Table 4). Thus, these parameters can be considered as potential indicators of $\mathrm{P}$ transformation under tillage, GM and residue management practices in RWS. These transformations act as a base for the decomposition of plants, aggregation in soil, soil tilth and availability of nutrients (Smith et al., 1993). Among the $\mathrm{PC} 1$ indicators, $\mathrm{NaOH}-\mathrm{P}_{\mathrm{o}}$ accumulates more in the form of very stable organic compounds in soil than $\mathrm{NaHCO}_{3}-\mathrm{Po}$ such as inositol phosphates and their phytins (Cosgrove 1976;Condron and Goh 1990),. In $\mathrm{PC}_{2}, \mathrm{NaHCO}_{3}-\mathrm{P}_{\mathrm{i}}$ was found to have significant correlation because $\mathrm{NaHCO}_{3}-\mathrm{Pi}$ is the most biologically available inorganic $\mathrm{P}$ fraction and $\mathrm{NaHCO}_{3}-\mathrm{Po}$ is considered as the easily mineralized P fractions in the form of phospholipids and nucleic acids (Harrison 1987). In PC3, HCl-P was representative variable to benefit largely as Ca-P and residual-P as $\mathrm{P}$ in mineral matrices and very stable humic substances.

The data point pertaining to the above variables are closely positioned to sustainable management practices (i.e. PTR $R_{W 25}+G M$ and $\left.\mathrm{ZTW}_{\mathrm{R} 100}\right)$. This might be due to the positive effect of legume crops grown in RWS has been reported to favor the net $\mathrm{C}$ buildup, associated aggregation and hydraulic properties (Masri and Ryan 2006). Bera et al., (2017) indicated a clear separation between ZT with crop residues and CT with no residue by PCA in wheat under RWS.

\section{Conclusions}

This study concludes that tillage intensity, residue retention and green manure significantly enhance $\mathrm{P}$ fractions within aggregates compared with conventional tillage practices. The crop residues addition along with zero tillage preferred the higher amount of $\mathrm{NaOH}-\mathrm{P}_{0}, \mathrm{NaHCO}_{3}-\mathrm{P}_{\mathrm{i}}$ and $\mathrm{HCl}-\mathrm{P}$ fractions in micro-aggregates than macro-aggregates and may act as dominant fractions in soil ensuring the $\mathrm{P}$ availability under RWS in sandy loam soils. The information on $\mathrm{P}$ fractions among different aggregates would be beneficial in the modification of current input management practices aimed for higher availability of $P$ to plants along with sustained crop productivity. Therefore, tillage, green manure and residue management should be recommended and popularized for the sustainability of RWS.

\section{Declarations}

\section{Acknowledgments}

Thanks are due to the Head, Department of Soil Science, Punjab Agricultural University for providing necessary laboratory and field facilities. This research did not receive any specific funding

\section{Ethical Approval}

Page $12 / 22$ 
Not applicable.

\section{Consent to Participate}

Not applicable.

\section{Consent to Publish}

Not applicable.

\section{Authors Contributions}

Sandeep Sharma set and conducts the experiment, Sukhjinder Kaur analysis of the data and provides the material, Sandeep Sharma and OP Choudhary writes this manuscript.

\section{Competing Interests}

The authors declare that they have no competing interests.

\section{Availability of data and materials}

All data generated or analysed during this study are included in this published article.

\section{References}

1. Ahmed W, Jing H, Kaillou L, Qaswar M, Khan MN, Jin C, Geng S, Qinghai H, Yiren L, Guangrong L, Mei S, Chao L, Dongchu L, Ali S, Normatov Y, Mehmood S, Zhang H (2019) Changes in phosphorus fractions associated with soil chemical properties under long-term organic and inorganic fertilization in paddy soils of southern China. PLoS ONE 14:e0216881

2. Alexander TG, Robertson JA (1968) Ascorbic acid as a reductant for total phosphorus determination in soils. Can J Soil Sci 48:217-218

3. Ana RDL, Hoogmoed W, Brussaard L (2008) Soil quality assessment in rice production systems: establishing a minimum data set. J Environ Qual 3:6-23

4. Barrios E (2007) Soil biota, ecosystem services and land productivity. Ecol Econ 64:269-285

5. Bera T, Sharma S, Thind HS, Singh Y, Sidhu HS, Jat ML (2017) Soil biochemical changes at different wheat growth stages in response to conservation agriculture practices in rice wheat system of north-western India. Soil Research 56:91-401

6. Bezerra RPM, Loss A, Pereira MG, Perin A (2015) Phosphorus fractions and correlation with soil attributes under no-tillage and crop-livestock integration systems in Cerrado of Goias. Semina Ciencias Agrarias 36:287-306

7. Bhan S, Behera UK (2014) Conservation agriculture in India - Problems, prospects and policy issues. International Soil Water Conservation Research 2:1-12

8. Biswas S, Gora H, Tapan P, Niharendu S, Tarik M, Roy S, Basak S, Biswapati NM (2017) Establishment of critical limits of indicators and indices of soil quality in rice-rice cropping systems under different soil orders. Geoderma 292:34-48

9. Castillo MS, Wright AL (2008) Soil phosphorus pools for Histosols under sugarcane and pasture in the Everglades, USA. Geoderma 145:130-135

10. Castro-Filho C, Lourenco A, Guimaraes MDF, Fonseca ICB (2002) Aggregate stability under different soil management systems in a red latosol in the state of Parana, Brazil. Soil Tillage Res 6:45-51

11. Chauhan BS, Mahajan G, Sardana V, Timsina J, Jat ML (2012) Productivity and sustainability of the rice-wheat cropping system in the Indo-Gangetic Plains of the Indian subcontinent: problems, opportunities, and strategies. Adv Agron 117:315369

12. Cheema HS, Singh B (1990) CPCS1-a computer program package for the analysis of commonly used experimental designs. Punjab Agricultural University: Ludhiana, India 
13. Chimdi A, Esala M, Ylivainio K (2014) Sequential fractionation patterns of soil phosphorus collected from different land use systems of Dire Inchine District, West Shawa Zone, Ethiopia. American-Eurasian Journal of Scientific Research 9:51-57

14. Condron LM, Goh K (1990) Nature and availability of residual phosphorus in long term fertilized pasture soils in New Zealand. J Agric Sci 114:1-9

15. Cosgrove DJ (1976) Microbial transformations in the phosphorus cycle. In: Alexander M (ed) 'Advances in microbial ecology', pp. 95. Plenum Press, New York

16. Dick RP, Kandeler E (2005) Enzymes in soils. Encyclopedia of Soils in the Environment, 448-456

17. Dick WA, Cheng L, Wang P (2000) Soil acid and alkaline phosphatase activity as pH adjustment indicators. Soil Biol Biochem 32:1915-1919

18. Dick WA, Tabatai MA (1992) Potential uses of soil enzymes. In: 'Soil Microbial Ecology: Applications in Agricultural and Environmental Management'. Marcel Dekker, New York, pp 95-127 Eds FB Metting)

19. Diez JA, Hernaiz P, Muñoz MJ, Torre ADL, Vallejo A (2010) Impact of pig slurry on soil properties, water salinization, nitrate leaching and crop yield in a four-year experiment in Central Spain. Soil Use Manag 20:444-450

20. Essington EM, Howard DD (2000) Phosphorus availability and speciation in long-term no-till and disk-till soil. Soil Sci 165:144-152

21. Gathala MK, Kumar V, Sharma PC, Saharawat YS, Jat HS, Singh M, Kumar A, Jat ML, Humphreys E, Sharma DK, Sharma S, Ladha JK (2013) Optimizing intensive cereal-based cropping systems addressing current and future drivers of agricultural change in the northwestern Indo-Gangetic Plains of India. Agriculture Ecosystem Environment 177:85-97

22. Gaynor JD, Findlay WI (1995). Soil and phosphorus loss from conservation and conventional tillage in crop production. Journal of Environmental Quality, 24, 734-741

23. Gianfreda L, Antonietta RM, Piotrowska A, Palumbo G, Colombo C (2005) Soil enzyme activities as affected by anthropogenic alterations: Intensive agricultural practices and organic pollution. Sci Total Environ 341:265-279

24. Grant CA, Flaten DA (2019) 4R management of phosphorus fertilizer in the northern Great Plains. J Environ Qual. doi:10.2134/jeq2019.02.0061

25. Gupta VVSR, Germida JJ (1988) Distribution of microbial biomass and its activity in different soil aggregate size classes as affected by cultivation. Soil Biol Biochem 20:777-787

26. Harrison AF (1987) Soil organic phosphorous: a review of world literature. C.A.B. International, Wallingford

27. Hangen E, Buczko U, Bens $O$ (2002) Infiltration patterns into two soils under conventional and conservation tillage: Influence of the spatial distribution of plant root structures and soil animal activity. Soil Tillage Res 63:181-186

28. Jat ML, Dagar JC, Sapkota TB, Singh Y, Govaerts B, Ridaura SL, Saharawat YS, Sharma RK, Tetarwal JP, Jat RK, Hobbs H, Stirling C (2016) Climate change and agriculture: adaptation strategies and mitigation opportunities for food security in South Asia and Latin America. Adv Agron 137:127-236

29. Jiao Y, Whalen JK, Hendershot WH (2006) No-tillage and manure applications increase aggregation and improve nutrient retention in a sandy-loam soil. Geoderma 134:24-33

30. Jiao XG, Gao CS, Lu GH, Sui YY (2011) Effect of long-term fertilization on soil enzyme activities under different hydrothermal conditions in Northeast China. Agricultural Sciences in China 10:412-422

31. Kibblewhite MG, Ritz K, Swift MJ (2008) Soil health in agricultural systems. Philosophical Transactions of the Royal Society B 363:685-701

32. Lal (1993) Tillage effects on soil degradation, soil resilience, soil quality, and sustainability. Soil Tillage Res 27:1-8

33. Lavelle P, Rodriguez N, Arguello O (2014) Soil ecosystem services and land use in the rapidly changing Orinoco River Basin of Colombia. Agr Ecosyst Environ 185:106-117

34. Liu XI, He YQ, Zhang H, Schroder JK, Li C, Zhou J, Zhang ZY (2010) Impact of Land Use and Soil Fertility on Distributions of Soil Aggregate Fractions and Some Nutrients. Pedosphere 20:666-673

35. Margenot AJ, Paul BK, Sommer RR, Pulleman MM, Parikh SJ, Jackson LE, Fonte SJ (2017) Can conservation agriculture improve phosphorus $(P)$ availability in weathered soils? Effects of tillage and residue management on soil P status after 9

Page $14 / 22$ 
years in a Kenyan Oxisol. Soil Tillage Res 166:157-166

36. Masri Z, Ryan J (2006) Soil organic matter and related physical properties in a Mediterranean Wheat-based rotation trial. Soil Tillage Res 87:146-154

37. Mega JA (1982) Phytate: Its chemistry, occurrence, food interactions nutritional significance and methods of analysis. J Agric Food Chem 30:1-9

38. Mitran T, Mani PK, Bandyopadhyay PK, Basak N (2018) Effects of Organic Amendments on soil physical attributes and aggregate-associated phosphorus under long-term Rice-Wheat cropping. Pedosphere 28:823-832

39. Montgomery D (2007) Dirt: The Erosion of Civilizations. University California Press, Los Angeles

40. Nandan R, Singh SS, Kumar V, Singh V, Hazra KK, Nath CP, Malik RK, Poonia SP, Solanki CH (2018) Crop establishment with conservation tillage and crop residue retention in rice-based cropping systems of eastern India: yield advantage and economic benefit. Paddy Water Environ 16:477-492

41. Nannipieri P, Laura G, Landi L, Giancarlo R (2011) Role of phosphatase enzymes in soil. Soil Biol Biochem 26:215-241

42. Olsen SR, Cole CV, Watanabe FS, Dean LA (1954) Estimation of available phosphorus in soils by extraction with sodium bicarbonate. In Circular. US Department of Agriculture., Washington, DC, pp.19

43. Priyadarshi R, Kumar S, Choudhary CD (2018) Phosphorus fraction dynamics in soil as affected by tillage and cropping system under irrigated agro-ecosystem. Journal of Pharmacognosy Phytochemistry 7:392-396

44. Ranatunga TD, Reddy SS, Taylor RW (2013) Phosphorus distribution in soil aggregate size fractions in a poultry litter applied soil and potential environmental impacts. Geoderma 192:446-452

45. Rigo AZ, Correa JC, Mafra AL, Hentz P, Grohskopf MA, Gatiboni LC, Bedendo G (2019) Phosphorus fractions in soil with organic and mineral fertilization in a crop-livestock integration system. Revista Brasileira de Ciencia do Solo 43:e0180130

46. Saikia R, Sharma S, Thind HS, Sidhu HS, Singh Y (2019a) Temporal changes in biochemical indicators of soil quality in response to tillage, crop residue and green manure management in a rice-wheat system. Ecol Ind 103:383-394

47. Saikia R, Sharma S, Thind HS, Singh Y (2019b) Tillage and residue management practices affect soil biological indicators in a rice-wheat cropping system in north-western India. Soil Use Manag 36:157-172

48. Sharma S, Vashisht M, Singh Y, Thind HS (2019) Soil carbon pools and enzyme activities in aggregate size fractions after seven years of conservation agriculture in a rice-wheat system. Crop Pasture Science 70:473-485

49. Sidhu HS, Singh M, Singh Y, Blackwell J, Humphreys E, Jat ML, Singh V (2015) Development and evaluation of the Turbo Happy Seeder for sowing wheat into heavy rice residues in NW India. Field Crops Research 184:201-212

50. Sithole NJ, Magwaza LS, Thibaud RG (2019) Long-term impact of no-till conservation agriculture and N-fertilizer on soil aggregate stability, infiltration and distribution of $C$ in different size fractions. Soil Tillage Res 190:147-156

51. Singh N, Dhaliwal JK, Sekaran U, Kumar S (2019) Soil hydrological properties as influenced by long-term nitrogen application and landscape positions under switchgrass seeded to a marginal cropland. GCB Bioenergy 11:1026-1040

52. Smith J, Halvorson J, Papendick R (1993) Using multiple-variable indicator kriging for evaluating soil quality. Soil Sci Soc Am J 57:743-749

53. Srinivasan V, Maheswarappa HP, Lal R (2012) Long term effects of topsoil depth and amendments on particulate and non particulate carbon fractions in a Miamian soil of Central Ohio. Soil Tillage Res 121:10-17

54. Sui Y, Thompson ML, Shang C (1999) Fractionation of phosphorus in a Mollisol amended with biosolids. Soil Sci Soc Am J 63:1174-1180

55. Tabatabai MA, Bremner JM (1969) Use of p-nitrophenyl phosphate for assay of soil phosphatase activity. Soil Biol Biochem 1:301-307

56. Thind HS, Sharma S, Singh Y, Sidhu H (2019) Rice-wheat productivity and profitability with residue, tillage and green manure management. Nutr Cycl Agroecosyst. 10.1007/s10705-018-09967-8

57. Verma S, Subehia SK, Sharma SP (2005) Phosphorus fractions in an acid soil continuously fertilized with mineral and organic fertilizers. Biol Fertil Soils 41:295-300 
58. Walkley A, Black CA (1934) An examination of the method of determination of organic matter and a proposed modification of the chromic acid titration method. Soil Sci 37:29-34

59. Wang JB, Chen ZH, Chen LJ, Zhu AN, Wu ZJ (2011) Surface soil phosphorus and phosphatase activities affected by tillage and crop residue input amounts. Plant Soil Environment 57:251-257

60. Wallis MG, Horne DJ (1992) Soil water repellency. Adv Soil Sci 20:91-146

61. Wei T, Zhang P, Wang K, Ding R, Yang B, Nie J, Jia Z, Han Q (2015) Effects of wheat straw incorporation on the availability of soil nutrients and enzyme activities in semiarid areas. PLoS One 10:e0120994

62. Wold S, Esbensen K, Geladi P (1987) Principal component analysis. Chemometrics Intelligent Laboratory Systems 2:37-52

63. Xu J, Han H, Ning T, Li Z, Lal R (2019) Long-term effects of tillage and straw management on soil organic carbon, crop yield, and yield stability in a wheat-maize system. Field Crops Research 233:33-40

64. Yadav BK, Tarafdar JC (2004) Phytase activity in the rhizosphere of crops, trees and grasses under arid environment. J Arid Environ 58:285-293

65. Zhang G, Xi M, Zhao Q, Lu Q, Jia J (2016) Soil quality assessment of coastal wetlands in the Yellow River Delta of China based on the minimum data set. Ecol Ind 66:458-466

66. Zhang ZS, Cao CG, Cai ML, Li CF (2013) Crop yield, P uptake and soil organic phosphorus fractions in response to short-term tillage and fertilization under a rape-rice rotation in central China. Soil Science Plant Nutrition 13:871-888

\section{Figures}




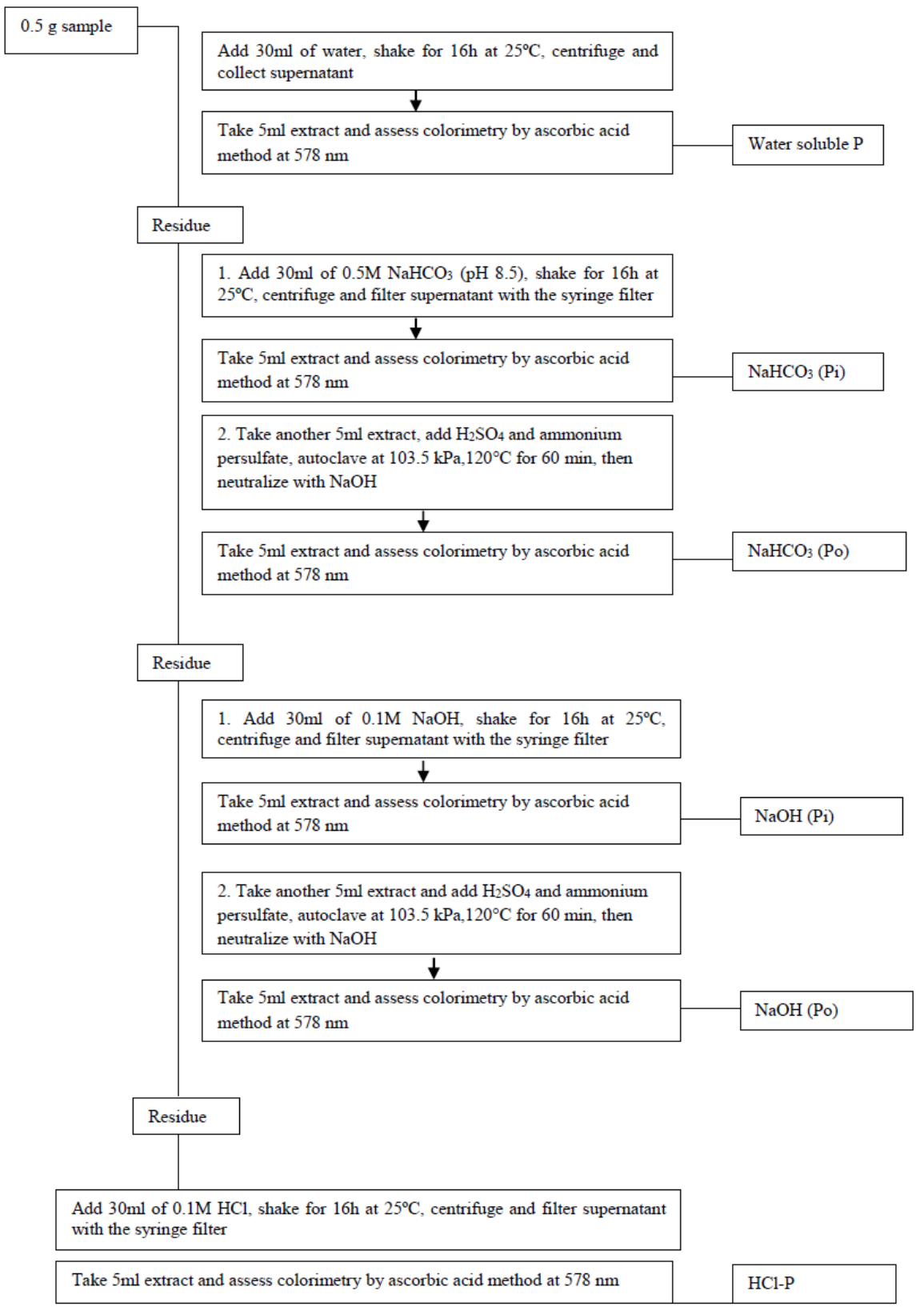

\section{Figure 1}

Sequential fractionation scheme for phosphorus 


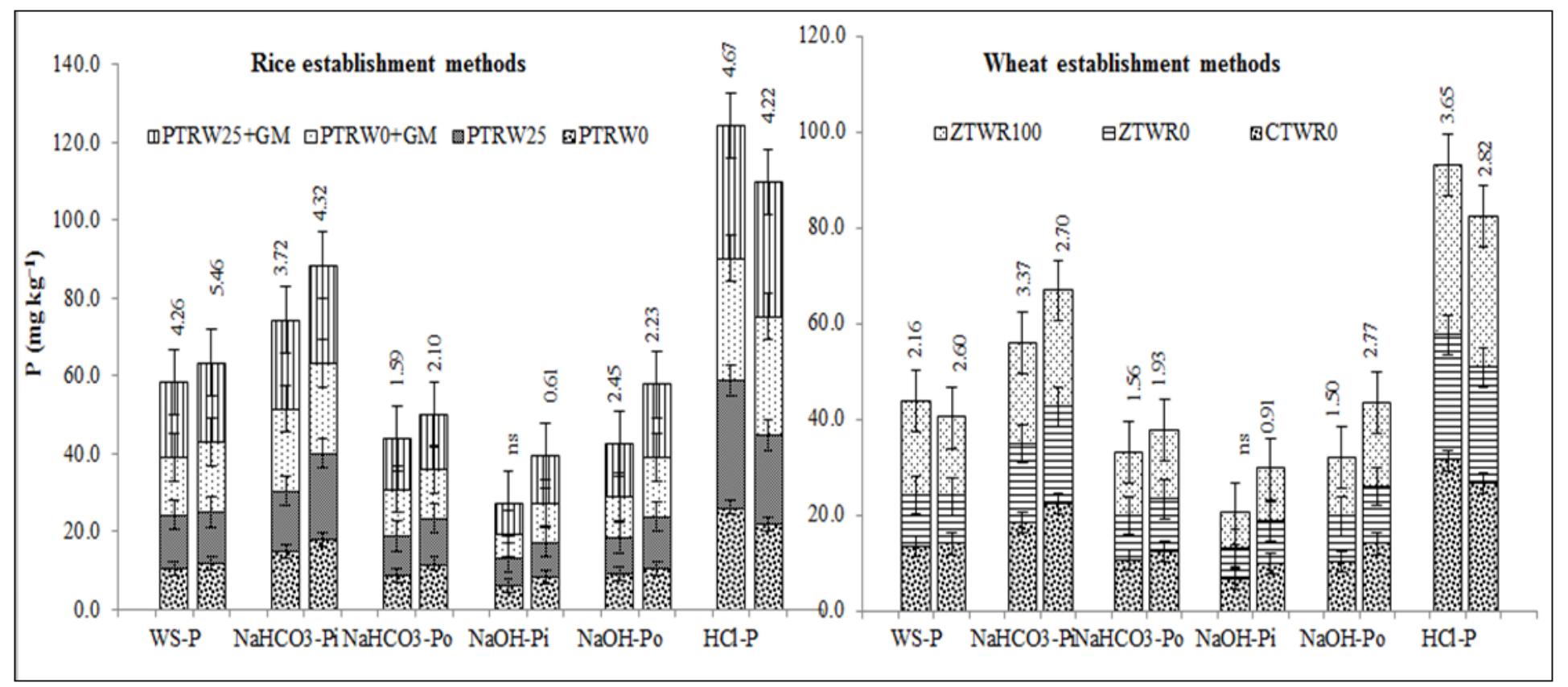

Figure 2

Effect of tillage, green manure and residue management practices on phosphorus fractions in micro-aggregate $(<0.25 \mathrm{~mm})$ and macro-aggregate $(>0.25 \mathrm{~mm}$ ) after five years of rice-wheat cropping system. Vertical bars are the standard errors of the mean $(p<0.05)$. First and second stacked bars indicate micro-aggregate and macro-aggregate, respectively. The values above the vertical bars represent least significant difference test

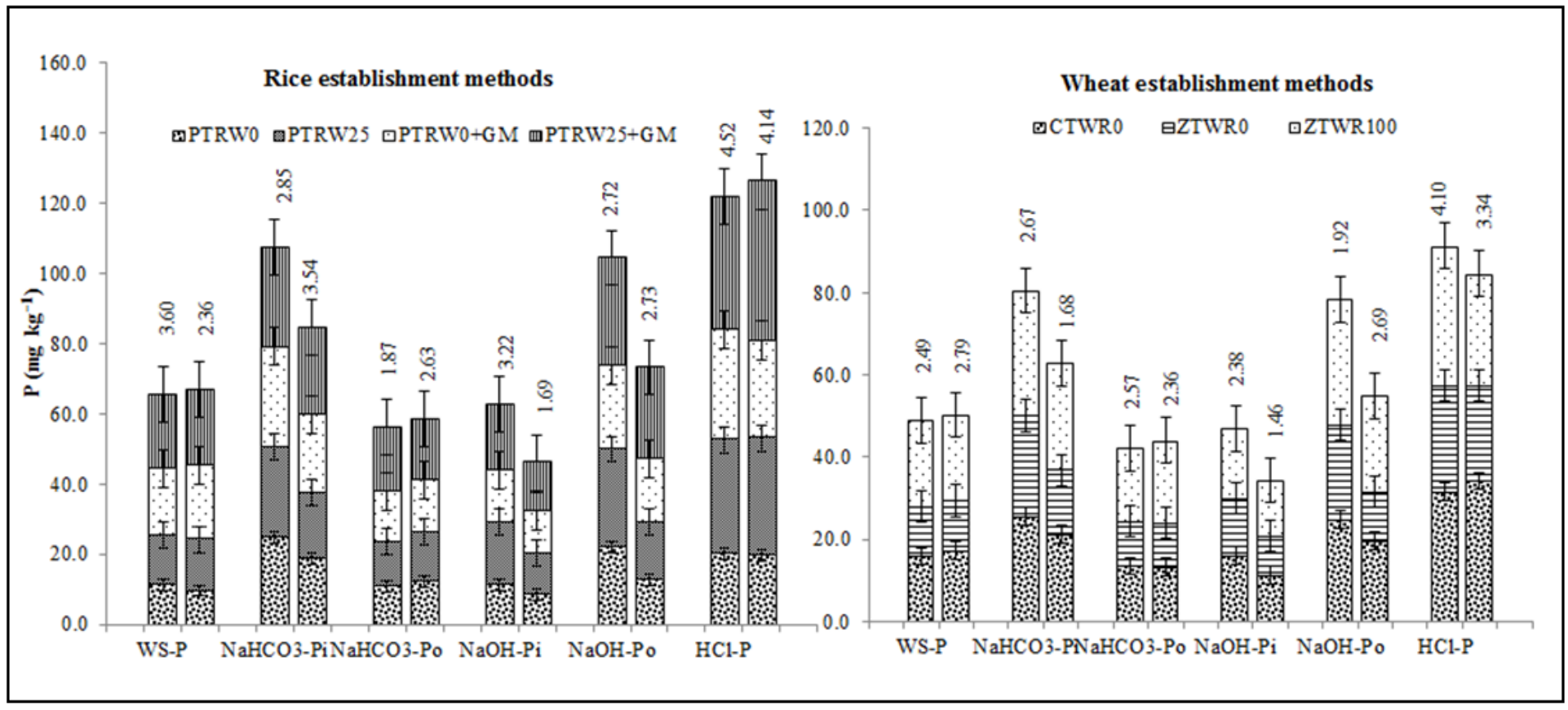

Figure 3

Effect of tillage, green manure and residue management practices on phosphorus fractions in micro-aggregate (1-2 $\mathrm{mm})$ and macro-aggregate (>2 $\mathrm{mm}$ ) after five years of rice-wheat cropping system. Vertical bars are the standard errors of the mean $(p<0.05)$. First and second stacked bars indicate 1-2 $\mathrm{mm}$ and $>2 \mathrm{~mm}$, respectively. The values above the vertical bars represent least significant difference test 


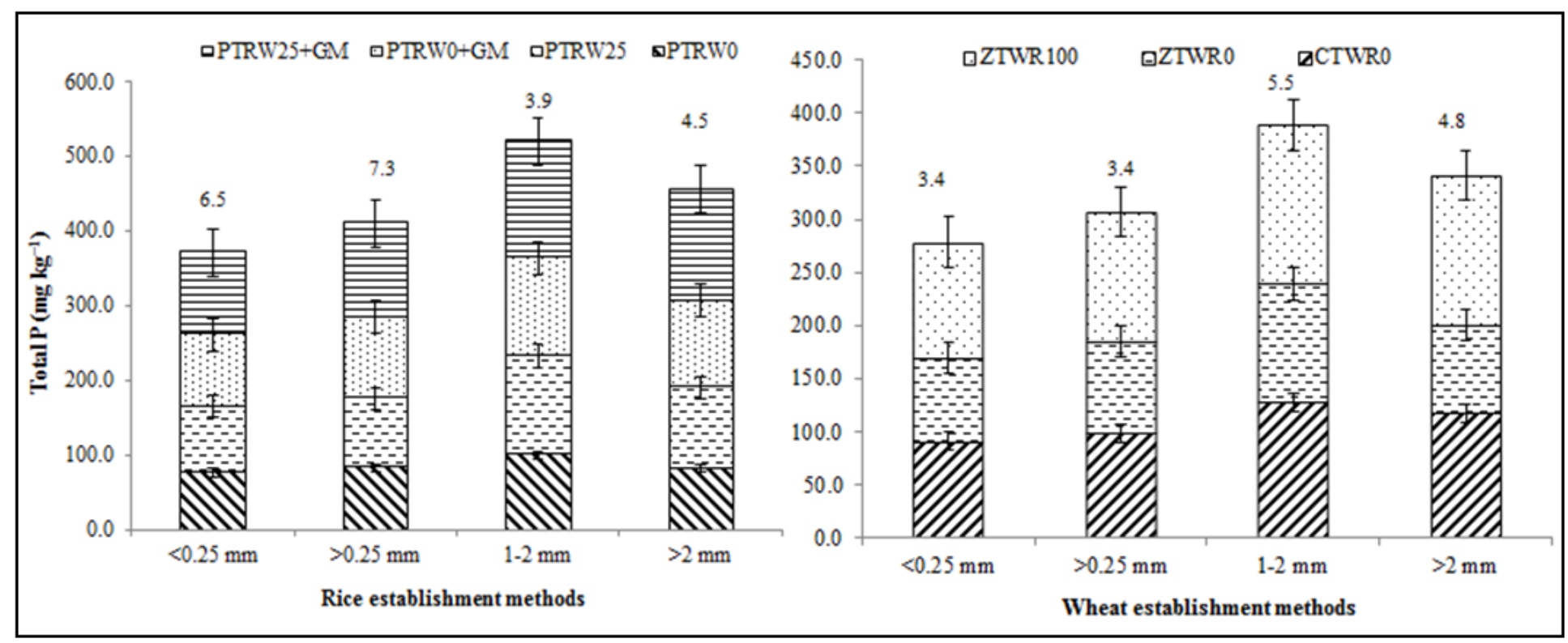

Figure 4

Effect of tillage, green manure and residue management practices on total phosphorus within aggregates after five years of ricewheat cropping system. Vertical bars are the standard errors of the mean $(p<0.05)$. The values above the vertical bars represent least significant difference test.

\begin{tabular}{|c|c|c|c|c|c|c|c|c|c|}
\hline \multirow{10}{*}{ 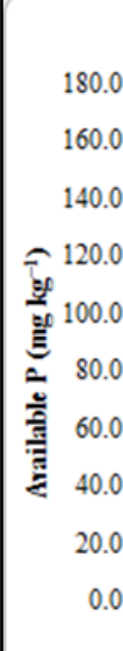 } & \multicolumn{4}{|c|}{ Rice establishment methods } & \multicolumn{5}{|c|}{ Wheat establishment methods } \\
\hline & aPTRWO & GPTRW25 & GPTRW0+GM & EPTRW25+GM & 140.0 & & 口CTWRO $\quad$ EZTWRO & 口ZTWR 100 & \\
\hline & & & & $=33$ & & & & 5.10 & \\
\hline & & & 青 & 3.30 & 120.0 & & &. & 3.40 \\
\hline & 5.70 & I & 原学 & 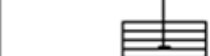 & 100.0 & 3.20 & 2.70 & & 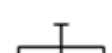 \\
\hline & 等 & = & 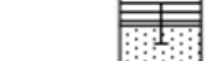 & 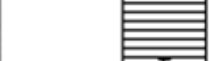 & 80.0 & I. & 1 & & \\
\hline & 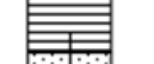 & in & & $\sqrt{1+3}$ & 60.0 & & & 4 & -1 \\
\hline & S & +1 & 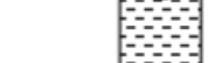 & -1 & 40.0 & -1 & - & 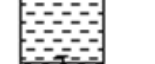 & 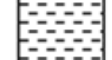 \\
\hline & 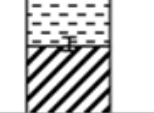 & OIII & 8 & $\theta$ & 20.0 & 8 & 8 & U & 8 \\
\hline & $<0.25 \mathrm{~mm}$ & $>0.25 \mathrm{~mm}$ & $1.2 \mathrm{~mm}$ & $>2 \mathrm{~mm}$ & & $<0.25 \mathrm{~mm}$ & $>0.25 \mathrm{~mm}$ & $1.2 \mathrm{~mm}$ & $>2 \mathrm{~mm}$ \\
\hline
\end{tabular}

Figure 5

Effect of tillage, green manure and residue management practices on available phosphorus within aggregates after five years of rice-wheat cropping system. Vertical bars are the standard errors of the mean $(p<0.05)$. The values above the vertical bars represent least significant difference test. 


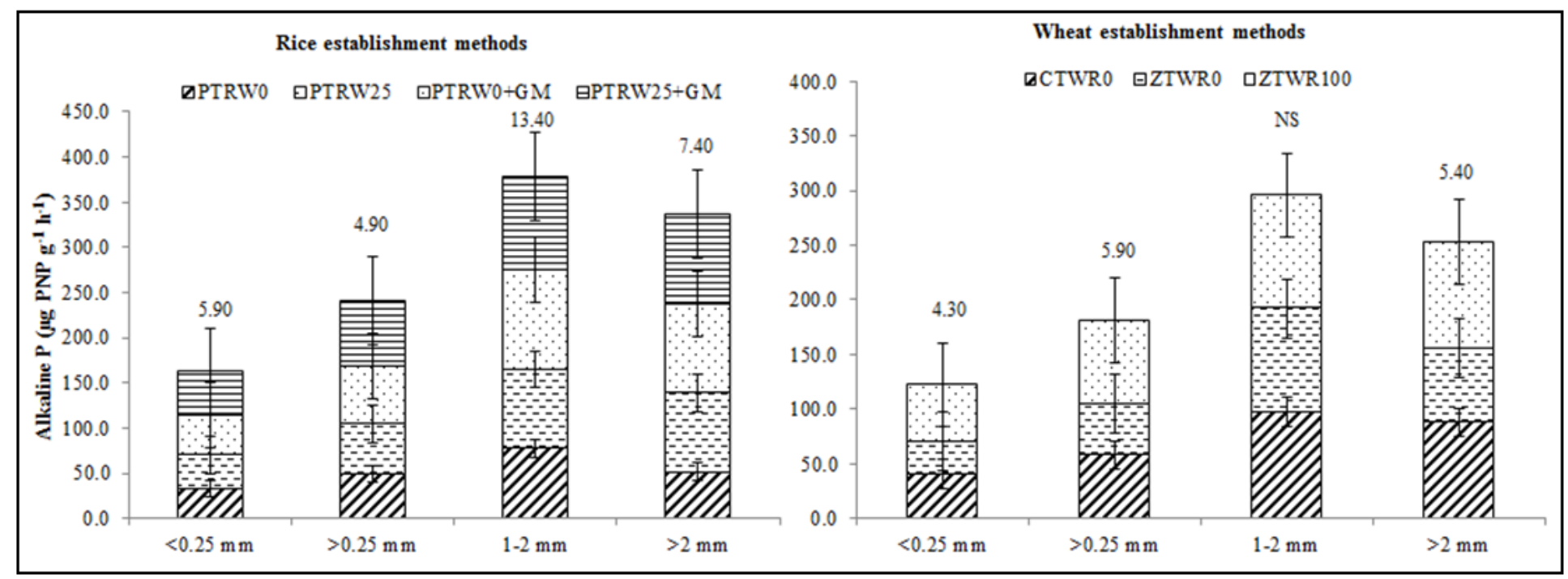

Figure 6

Effect of tillage, green manure and residue management practices on alkaline phosphatase within aggregates after five years of rice-wheat cropping system. Vertical bars are the standard errors of the mean $(p<0.05)$. The values above the vertical bars represent least significant difference test.

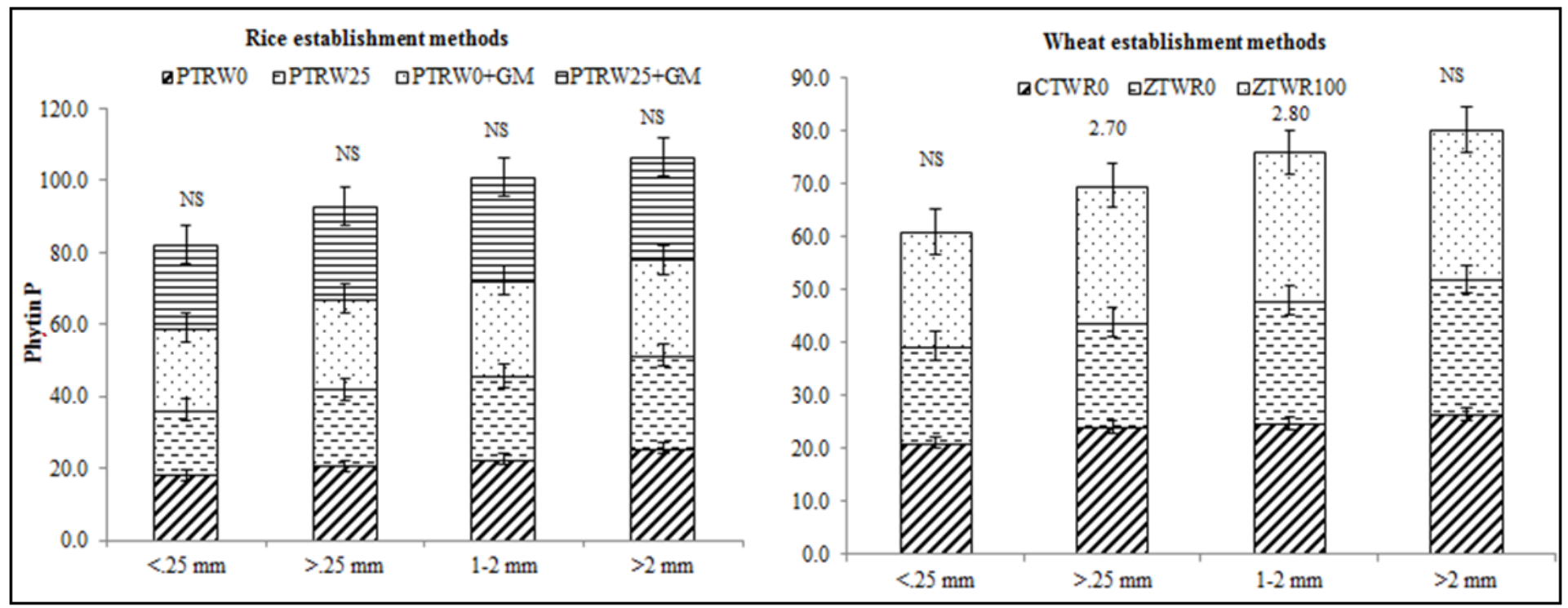

Figure 7

Effect of tillage, green manure and residue management practices on phytin-P within aggregates after five years of rice-wheat cropping system. Vertical bars are the standard errors of the mean $(p<0.05)$. The values above the vertical bars represent least significant difference test. 


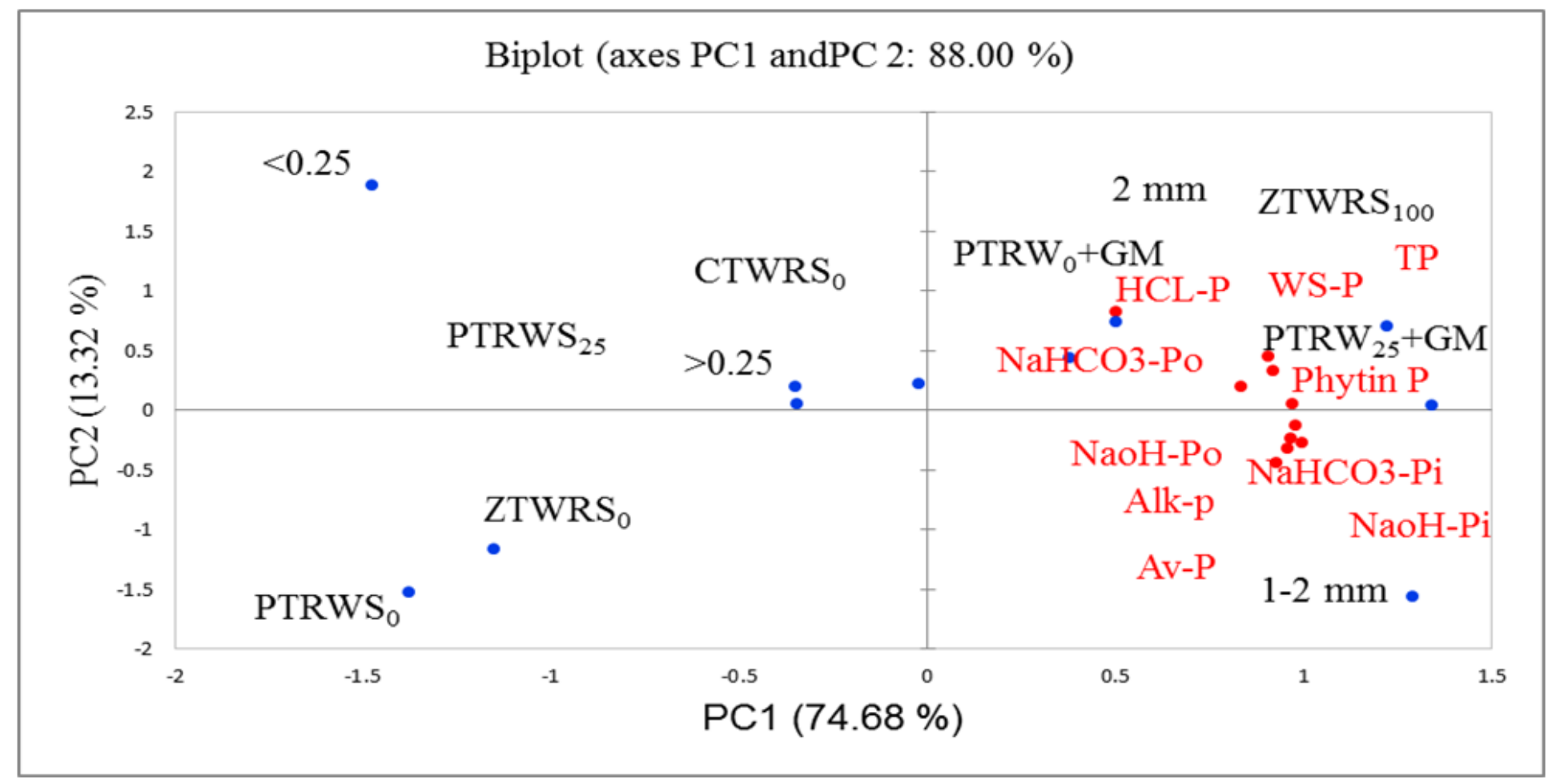

Figure 8

PTRWS0-puddled transplanted rice with no wheat straw, PTRWS25-puddled transplanted rice with 25\% anchored wheat straw retained, GM-Green manure, CT-R-conventional tillage wheat with rice straw removed, ZT-R-zero tillage wheat with rice straw removed, ZT+R-ZTW with $100 \%$ rice straw retained as surface mulch, WS-P Water soluble phosphorus, TP Total phosphorus, Av-P Available phosphorus, Alk-P Alkaline phosphatase

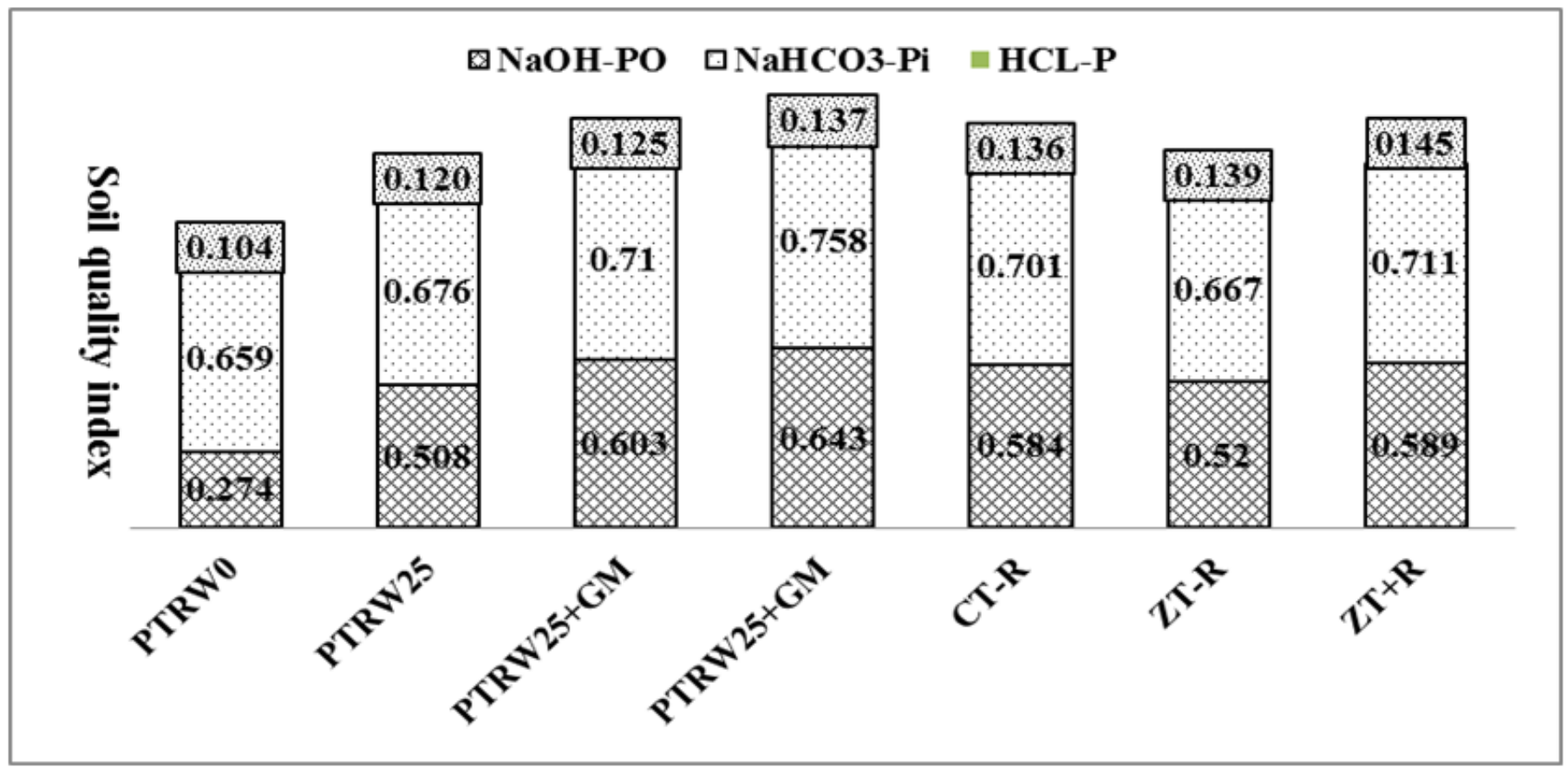

Figure 9

Average effect of rice and wheat treatments on soil quality index and the individual contribution of each of the key indicators. Note- PTRW0-puddled transplanted rice with no wheat straw, PTRW25-puddled transplanted rice with 25\% anchored wheat straw 
retained, GM-Green manure, CTWRO-conventional tillage wheat with rice straw removed, ZTWRO-zero tillage wheat with rice straw removed, ZTWR100-ZTW with 100\% rice straw retained as surface mulch; Po- Organic phosphorus, Pi- inorganic phosphorus

\section{口NaOH-PO घNaHCO3-Pi 口HCL-P}

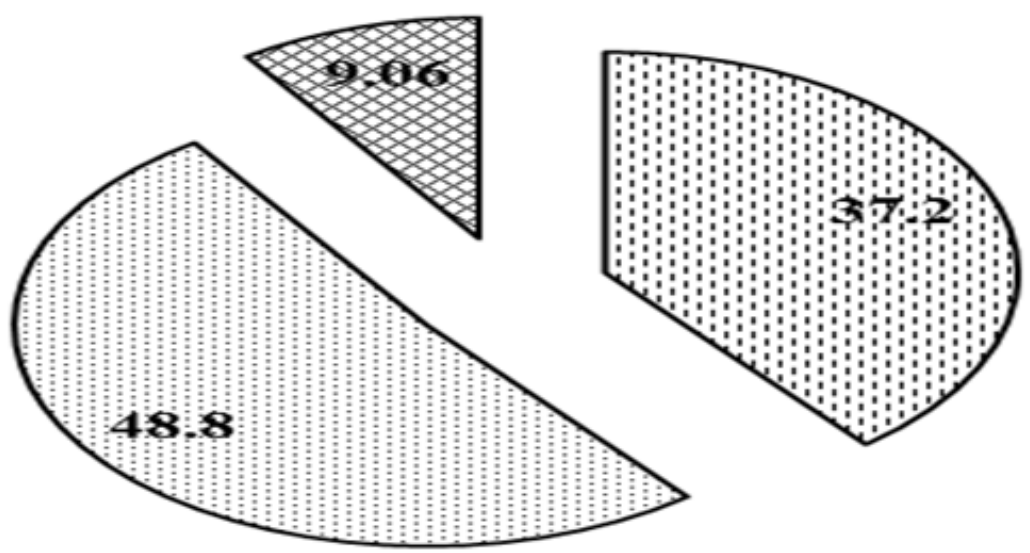

Figure 10

Overall contribution of the selected soil quality indicators to soil quality index

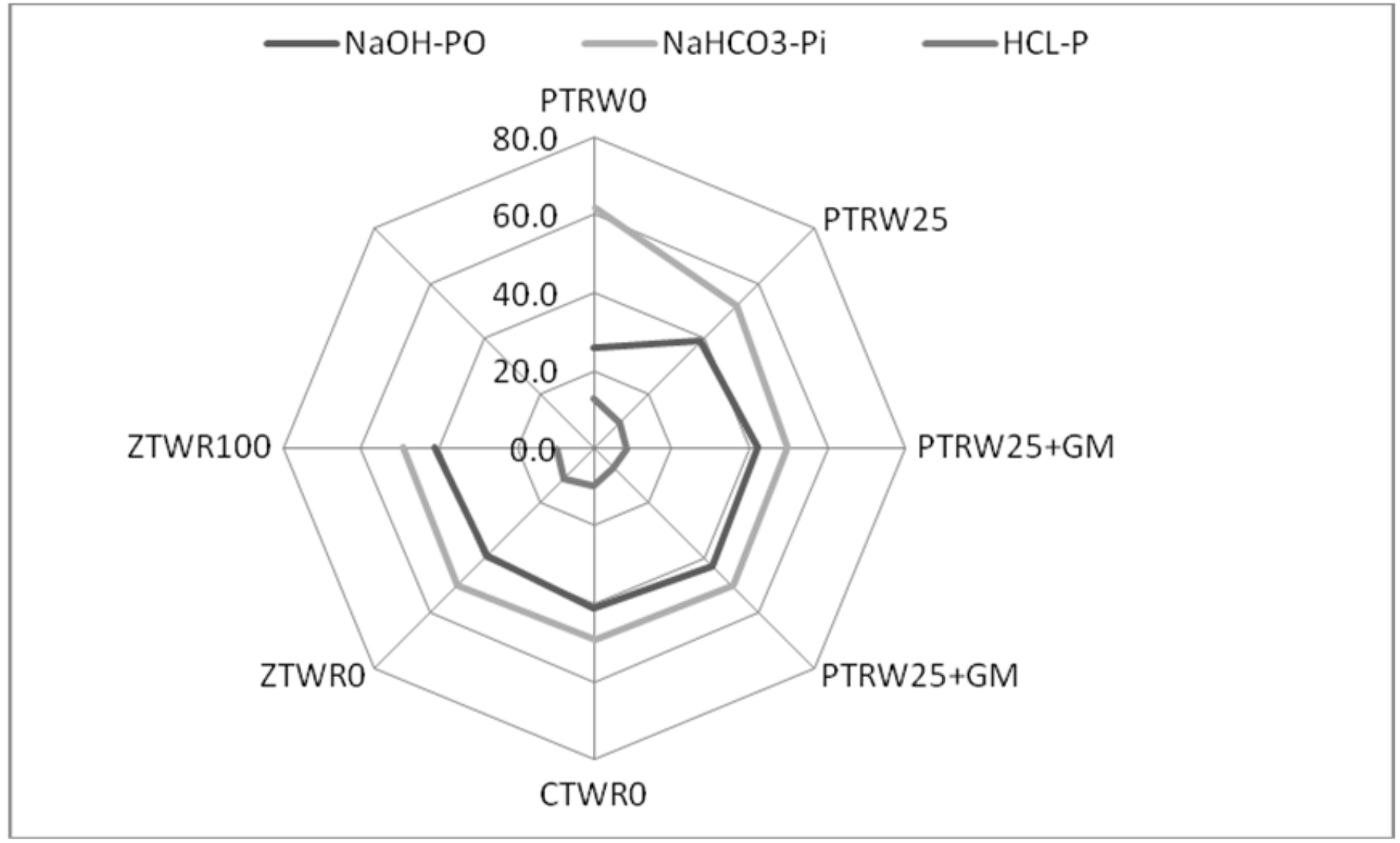

Figure 11

Contribution (\%) of selected indicators to soil quality under rice and wheat treatments PTRWS0-puddled transplanted rice with no wheat straw, PTRW25-puddled transplanted rice with $25 \%$ anchored wheat straw retained, GM-Green manure, CTWR0conventional tillage wheat with rice straw removed, ZTWR0-zero tillage wheat with rice straw removed, ZTWR100-ZTW with 100\% rice straw retained as surface mulch; FC-Field capacity 